DOI:10.1080/13683500.2012.743973/.

\title{
Maritime tourism and terrorism: customer perceptions of the potential terrorist threat to cruise shipping
}

\author{
Clare Bowen, Paul Fidgeon \& Stephen John Page*
}

\begin{abstract}
Maritime terrorism is a neglected area of research in tourism, particularly the use of scenario planning to understand potential threats to the cruise industry. Since the events of 9/11, terrorism, and the threat of terrorism, has become a major concern within the tourism industry. This paper analyses tourist perception of perceived terrorist threats given that many ships are American owned. Using the scenario analysis presented by Greenberg, Chalk, Willis, Khilko and Ortiz (2006), this study suggests that an attack on a cruise ship is a distinct possibility. Indeed, $44 \%$ of respondents questioned perceived the possibility of a terrorist attack on a cruise ship to be likely despite the fact that safety and security is seen by the industry as a 'hallmark' of cruising. Differences in attitude among potential passengers revealed a high level of confidence in the cruise ship companies. This finding is particularly marked among more experienced cruise ship passengers. However, this did not necessarily preclude the possibility of security measures being improved. All passengers appeared generally resigned to the fact that risk is associated with travel in the twenty first century and welcomed any efforts by cruise shipping companies to improve safety and security.
\end{abstract}

\section{Introduction}

The relationship between marine-based travel and tourism has a well-developed literature that encompasses both the role of passenger ferries in providing sea crossings for tourist travel (i.e. tourist travel as utility) and where the marine context is the focus of the tourist experience (i.e. cruising) (Page, 2009). Within the marine transportation literature, the interconnection with the wider marine research agenda has seen only a limited development, particularly in terms of issues of traveller safety and security. Much of the research knowledge in this area emanates from travel medicine with the emphasis on traveller well-being and protection in confined areas where infectious diseases can spread rapidly, as evidenced by outbreaks of the norovirus. What is not particularly well articulated in the research literature is the interconnection with other cognate areas of research in political science (Quester, 1986) (i.e. terrorism) and two other aspects of management research (i.e. scenario planning and business continuity planning and resilience). These three areas are presented for the first time in the tourism literature to demonstrate the growing importance of potential tourist threats to cruise shipping to conceptualise and contextualise the issue in terms of the notion of maritime terrorism. The Council for Security Cooperation 
describe maritime terrorism as 'acts and activities within the maritime environment using or against vessels or fixed platforms at sea or in a port and liable to affect passenger or personnel, coastal facilities or settlements' (cited in Greenberg et al, 2006: 84). This all-encompassing definition illustrates both the geographical scope of marine terrorism and the broad range of settings in which cruise ships and their passengers may potentially be targeted by terrorists. Marine terrorism has largely been overlooked in existing syntheses of transport and tourism research (e.g. Page, 2009) although it is a germane area for research given the wider terrorist risks identified in marine environments by Greenberg et al (2006).

This paper offers two innovative contributions to tourism research: first, one of the predominant research paradigms in current studies of tourism is the notion of the destination as the containing context for study (i.e. the destination as the study focus for tourism). Yet cruise ships by their very nature are not fixed at any one point in time and space to a specific form of infrastructure and so are highly mobile in a marine setting. Yet as a mode of travel, it shares many of the safety and security debates that affect aviation post 9/11. However, in the case of cruising, there is virtually no academic research focusing on tourists as potential victims outside of land-based destinations or in-transit via air-based modes of travel. Secondly, this study develops a strand of research emanating from a landmark study by the futures research organisation The Rand Corporation (Greenberg et al, 2006) that undertook a scenario planning exercise focused on maritime terrorism, in which cruising was one component. In this respect, these two contributions combined with a primary research study extending The Rand Corporation's influential research provides an innovative focus for the analysis of tourist transport research in terms of maritime terrorism. This study also provides an analysis of cruise ships as terrorist targets from a consumer perspective which is comparatively rare in scenario planning research that tends to be supply-led and organisationally focused and does not normally undertake consumer assessments of the likely risks and scenarios occurring.

The growing international interest in two inter-related dimensions of maritime terrorism - piracy (see Birnie, 1987; Menefee, 1988 for a review) and the probability of terrorist attack and the loss of life through substantial collateral damage to a vessel has not been a focus for tourism research. For example, in 2011 there were 439 acts of piracy, of which 275 occurred off the coast of Somalia although piracy is not normally associated with the terrorism agenda as the term hijacking is a more common usage even though it is little more than an issue of semantics. Safety issues surrounding cruising and the provision for passengers in emergency situations have also received an unfortunate growth in interest following the sinking of the cruise ship Costa Concordia in 2012 (Volo and Pardew, 2012). Concerns have been raised about the safety of new generation large cruise ships given the debates in the literature about the highly unlikely probability of such an event occurring due to the construction of cruise ships with double hulls (Greenberg et al, 2006). Yet as the accident affecting this cruise ship suggests there are inherent vulnerabilities to cruise ships which accidents and potential terrorist attacks could pose to its passengers. When one draws comparisons with the tragic loss of life on board the Herald of Free Enterprise passenger ferry in 1987 at an insurance cost of US\$110 million where 193 passengers died, this is comparatively small compared to the scale and number of passenger's modern day cruise lines carry. A passenger population of 2000 and 1000 crew is not uncommon with plans for cruise ships to carry 3000 passengers from 2015. Therefore, the increased size of the potential economic 'loss' through a terrorist attack is much greater along with the potential loss of life. This paper challenges the notion of the 'safe' cruise epitomised by Dowling (2006: 427) that 'safety and security are a hallmark of cruising', highlighting the greater understanding needed towards cruise ship vulnerability to terrorist attack through the contribution of 
scenario planning and the response of consumers to such risks. The research reported in this study seeks to quantify and understand the extent to which cruise ship passengers understand safety and security risks as a traditionally risk averse clientele (Wilkes, Pendergast and Leggat 2006; Tarlow 2006a, b). The paper examines a number of interconnected literatures to provide a better understanding of marine terrorism and tourism, namely scenario planning to assess the scope, scale and risk of terrorist attack on cruise liners and the risk perception of tourists as travellers. However, prior to examining the literature, it is useful to provide an overview of cruise ships as floating destinations and their vulnerability to terrorist attack.

\section{The Cruise Shipping Industry: An Overview}

A growing academic literature is now developing on the emergence of cruising as a popular leisure activity (Cartwright and Baird, 1999; Douglas and Douglas, 2001; Quartermaine and Peter, 2006; Gibson, 2006a; Grace,2008; Holloway, Davidson and Humphreys 2009; Hannafin and Sarna, 2010; Ward, 2010; Mancini, 2011). One strand of research in this literature relates to the role of marketing to reposition the activity as a product by reinventing itself not only as a means of transportation but rather as a 'holiday experience'. From the 1960s, line voyages (or sailings between two points) came to be replaced by pre-arranged itineraries featuring multiple points of calls. Time at sea was to be filled with a heady mix of entertainment and gourmet dining, while port visitation allowed for the possibility of shore excursions, trips and visits. This has recalled the heydays of 1930s cruising as a luxury product and experience. Some researchers have argued that the Western focus of such a transformation in cruising to a luxury product epitomising conspicuous consumption has made it a legitimate target for terrorists.

With changes in product and product positioning, cruise line companies have initiated changes in the market and corresponding ship design (Dale, 2005; Walker and Walker, 2011). Product development has seen the introduction of fly cruises whereby passengers fly out to meet their ship at the embarkation port; cruise and stay where passengers can lengthen their cruise by staying in a resort or city typically by their embarkation/disembarkation port; repositioning cruises featuring sailings at the start or end of a season when ships have to be repositioned for the forthcoming season; freighter cruising featuring trips on cargo vessels; round the world, river and special interest cruises - the latter featuring cruises based around a specific theme or point of tourist interest, typically music sport health and fitness.

Changes in cruise ship design has seen movement away from the 'classic ships' of the 1960s and 1970s to the modern ships of the 1980s and 1990s and what have termed 'third generation ships' of the new millennium (Mancini,2004; Ward, 2010) (see Table 1).

Table 1 Comparisons in cruise ship design

\begin{tabular}{|l|r|c|}
\hline \multicolumn{1}{|c|}{ Classic Ships } & \multicolumn{1}{c|}{ Modern Ships } & $\underline{\text { Third Generation Ships }}$ \\
\hline$>$ Built from wood and natural & $>$ Made from metal. & Ships measuring over 100,000 \\
materials. & $>$ Large public areas. & tonnes are common place. \\
$>$ Small public areas. & $>$ Hulls have smaller drafts, & Mega ships catering for more \\
$>$ Hulls have deep drafts which & thus ports are more & $>$ Vibration less propulsion \\
\hline make some ports inaccessible & accessible. & than passengers. \\
\hline
\end{tabular}




\begin{tabular}{|c|c|c|c|c|c|}
\hline & and require tendering. & & Larger windows & & systems. \\
\hline$>$ & Small porthole sized windows. & $>$ & Fewer obstructed & $>$ & Innovative design including \\
\hline$>$ & Many staterooms have & & stateroom views. & & widening the hull and splitting \\
\hline & obstructed views. & $>$ & Increased number of & & the ship to have balconies \\
\hline$>$ & Staterooms with balconies are & & staterooms with a balcony. & & facing both the sea and \\
\hline & rare. & $>$ & Larger swimming pools. & & overlooking a promenade. \\
\hline$>$ & Staterooms sizes typically large & $>$ & More passenger facilities & $>$ & Freshwater swimming pools. \\
\hline & in size. & & including casinos, theatres & $>$ & Increased dining options. \\
\hline$>$ & Promenade decks are & & and discos. & $>$ & Increased facilities for \\
\hline & common. & $>$ & Standardized stateroom & & children; cruising as a family \\
\hline$>$ & Can travel up to 30 knots. & & size. & & experience. \\
\hline$>$ & Smaller swimming pools. & $>$ & Easier pedestrian flow & $>$ & Pioneering features, open air \\
\hline$>$ & Typified by Royal Viking Lines & & through ship. & & cinemas, shopping malls, spa, \\
\hline & Sky and Star $(21,891$ tonnes. & $>$ & Can travel between $20-25$ & & waterslides, zip lines, rock \\
\hline & Passenger Capacity 1,237 plus & & knots. & & climbing walls, ice skating \\
\hline & crew) & $>$ & Typified by Carnival Cruise & & rinks, aqua- theatres, areas \\
\hline & & & Lines' Paradise and & & with grass and trees to name a \\
\hline & & & Sensation (70, 390 tonnes. & & few. \\
\hline & & & Passenger Capacity 2,183 & $>$ & Typified by Royal Caribbean \\
\hline & & & plus crew) & & Internationals' Oasis of the \\
\hline & & & & & Seas and Allure of the Seas \\
\hline & & & & & (222,900 tonnes. Passenger \\
\hline & & & & & Capacity 5,400 plus crew) \\
\hline
\end{tabular}

Source: Adapted from Mancini (2004) and Ward (2010)

Cruising can no longer be regarded as an option for retirees and the rich (Keynote, 2008). The cruise shipping industry in the twenty-first century attempts to cater to all markets, budgets and geographical regions. Mancini (2011) reports that only $20 \%$ of cruise passengers are over sixty years of age dispelling the popular myth that cruising is an 'old persons' holiday. Indeed Gibson (2006b) reports the fastest growing market is in the 25-40 age group. As a result it has become increasingly difficult to define the 'average' cruise ship passenger (Mancini, 2011).

In its effort to diversify its product, the cruise shipping industry has constantly searched for new geographical regions in which to cruise and new ports of call. Currently the world's largest and most popular routes are located in just seven regions of the world. These include the Caribbean, Mexico, Canada and the USA (including Alaska and the Panama Canal); The Far East and Pacific Islands, The Baltic, Europe, West Africa and the Atlantic Islands (including the Canaries and Azores) and the rest of the world (essentially the Middle East and Australasia)(Holloway et al, 2009).

Itineraries sailing around the Caribbean have traditionally proved popular with the American market due to the close proximity of the islands to the United States. The emergence of Europe as an important cruise 
destination reflected in Royal Caribbean International's ( $\mathrm{RCl}$ ) decision to redeploy half of its fleet to Europe from North America for the 2011 summer season (Seaview Cruises). For experienced cruisers seeking new and exciting destinations Crystal Cruises reported the inclusion of Tripoli Libya to its Italian Splendour itineraries prior to the start of the civil war (Fearis, 2011). Elsewhere in 2010, RCl were the first cruise line to base a ship in the Middle East featuring seven night sailings around the United Arab Emirates. Luck, Maher and Stewart (2010) indicates that Antarctic cruises are becoming one of the fastest growing market sectors in cruise shipping with a capacity of just less than seven million bed days up from 4.2 million in 2000.

While the cruise shipping industry appears to be a highly competitive sector of the tourism industry featuring a range of companies, in reality the industry is dominated by just two core players (Ward 2010). Consolidation in the market has seen the industry dominated by Carnival Corporation PLC and Royal Caribbean Cruise Lines. Together the two companies have a combined market share of $78.4 \%$ of the world cruise market (Cruise Market Watch, 2010). Both have a number of brands in their product portfolio that ensure they are able to cater to a range of different markets and customer wants and needs as illustrated in Figure 1. In the UK, the cruise market has seen consistent growth despite more constrained patterns of leisure spending, with passenger numbers from the Passenger Shipping Association recording a growth from 1.53 million trips a year in 2009 to 1.65 million in 2010 to 1.71 in 2011 with forecasts of further growth for 2012. However these 2012 forecasts predate the Costa Concordia accident that led to an initial drop or delayed bookings in the peak booking month of January. Nevertheless what these statistics show is that cruising in a UK context has been relatively resilient as an activity when airlines have been forced to cut capacity and even ground aircraft due to a drop in demand.

Figure 1: Carnival Corporation PLC \& Royal Caribbean Cruise Lines brand portfolio
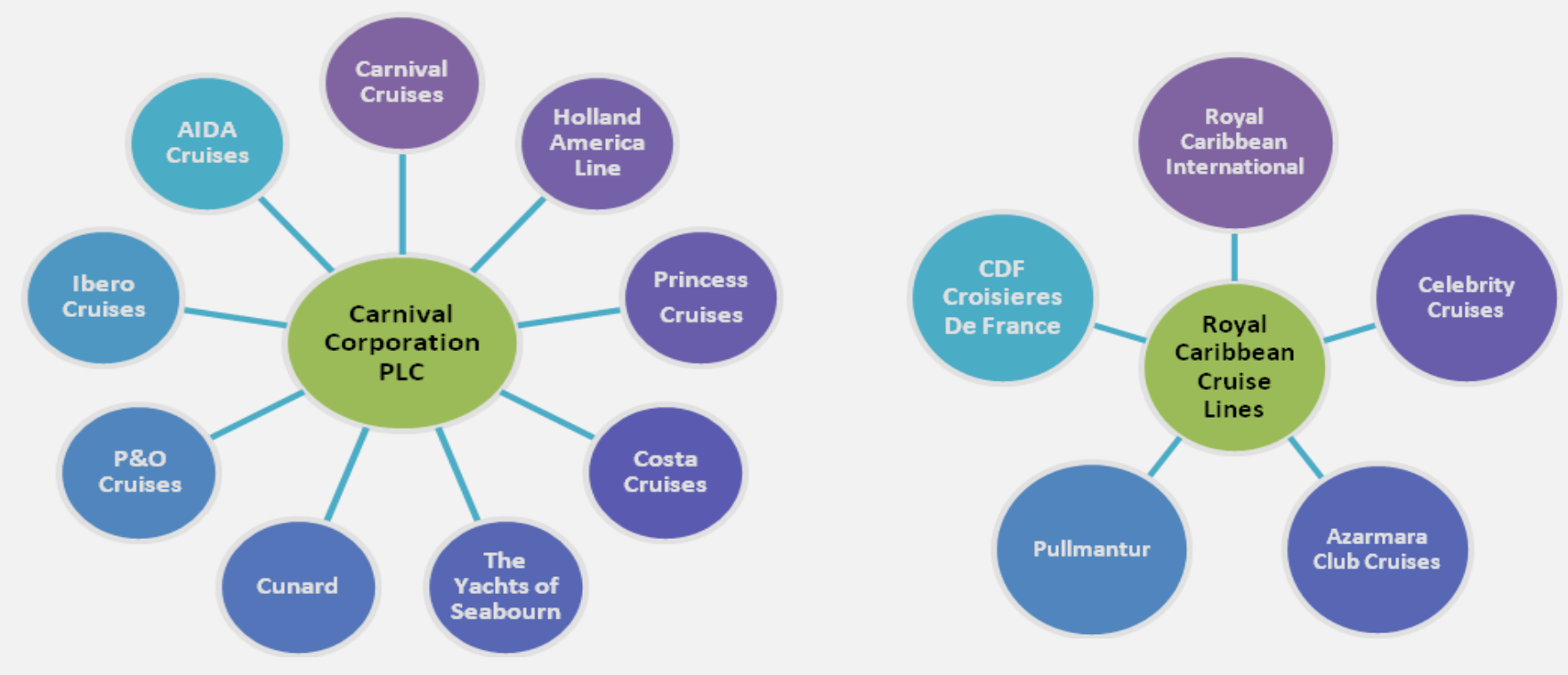

With this growing commercialisation of the cruise industry, it is also pertinent to examine a parallel development in business and management studies - the rise of research on business continuity and resilience. This assumes an important position in cruising in view of the large fixed capital investment in 
cruise lines and its perceived vulnerability post 9/11 as travellers and travel-related infrastructure became legitimate targets for terrorists.

Research on business continuity is concerned with how businesses make plans for the possible effects of shock events or crises on their activities (such as a terrorist threat). An associated stream of research which is particularly relevant is scenario planning (Page,Yeoman, Munro, Connell and Walker, 2006; Page, Yeoman, Connell, and Greenwood, 2010). Scenario planning can be defined as 'the process of trying to understand uncertainty associated with the future' (Page et al, 2006: 647). It helps to create choices based on looking at alternative possibilities framed around three questions: what may happen (possible futures), what is likely to happen (probable futures) and what we would prefer to happen (preferable futures). In each case an attempt is made to ascertain how changes in (tourist) demand might shape the future. For example, in the UK VisitBritain has examined forecasts which identify that the number of people aged over 65 will be greater than those aged under 16 by 2014 . The implications for the tourism sector is that it will need to be attuned to the needs of this growing discerning and lucrative market, many of whom will have experiences of overseas travel. Scenario planning in tourism has been used in situations as diverse as identifying the strategic response of national tourist organisations to a potential influenza pandemic (Page et al, 2006) through to transportation planning (Page, 2009; Page et al, 2010). In each case its use is to identify the range of risks and challenges which individual businesses and organisations may face. Page et

al (2010: 101) notes 'scenario planning is increasingly being used by organisations to consider the uncertain elements in the business environment to try to improve our foresight, to challenge our existing assumptions about how the world works'. It is one element of futures research (see Bradfield, Wright, Burt, Cairns, van der Heijden (2002) for more detail) and it performs two important functions: 'risk management, where scenarios enable strategies and decisions to be tested against possible futures, while the other is creativity and sparking new ideas' (Dunker and Greig, 2007: 210). Where such an approach is combined with consumer-oriented research, as illustrated by this paper, it has the potential to anticipate crises and foster the adaptive organisational learning required to develop new safety strategies as well as improving business resilience under conditions of crisis or emergency so as to improve organisational readiness for such events (Bradfield et al, 2005). Where such an approach is combined with consumeroriented research, as illustrated by this paper, it has the potential to anticipate crises and foster the adaptive organisational learning required to develop new safety strategies as well as improving business resilience under conditions of crisis or emergency so as to improve organisational readiness for such events (Bradfield et al, 2005). Most cruise ship companies have undertaken such exercises and have resilience measures in place in terms of potential threats but this is largely based on hypothetical futures and some understanding of past risks (i.e. the Rand Corporation database of previous maritime terrorist events was used to assess future risk by Greenberg et al, 2006). Therefore, this study is extremely relevant in the context of cruising as the scope of risks identified in the major study by The Rand Corporation (Greenberg et al, 2006) depicted the key vulnerabilities facing the cruise ship industry in relation to tourism, as outlined in Figure 2. These provide a basis upon which our study was able to assess the risk from a scenario planning perspective and then survey consumers about their understanding of the risks.

\section{Figure 2 here}

Figure 2. Key Scenarios Relating to Terrorism and Cruise Ships

Source: Developed from Greenberg et al (2006) 


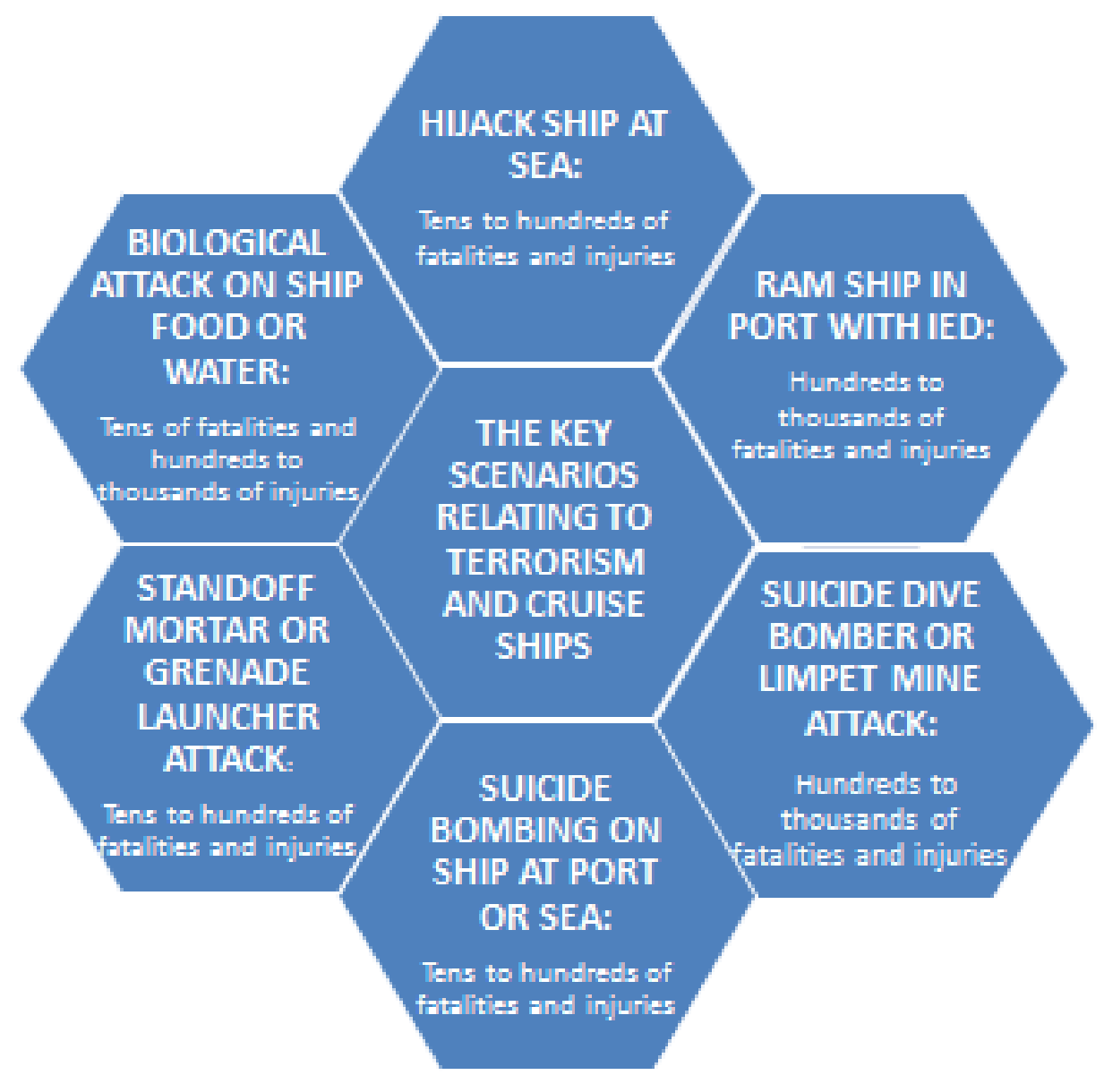

What Figure 2 illustrates is that large modern cruise ships are a potential target for terrorists when anchored off-shore or when passengers are embarking/departing alongside the publicly available itineraries which document their route. Greenberg et al's (2006) scenario planning research has identified the previous extent of suicide bombings and terrorist attacks in an effort to identify the probability of specific risks from terrorism. Their study was based upon a combination of historical data regarding previous attacks, and on a series of interviews with counterterrorism experts. Information on threat and vulnerability were used to estimate relative risk in connection with various attack scenarios. Qualitative methods for generating risk estimates involved the use of defined ordinal scales to assess terrorists' intents and capabilities, target vulnerabilities, and attack consequences. Greenberg's principal findings were that the highest risk threats passengers were likely to encounter emanate from an on-board bomb, an IED attack or food/water contamination. Piracy and the risk of hijack were considered a much lower risk. Their study concludes that many perceptions of maritime terrorism risks do not necessarily align with the reality of threats and vulnerabilities. First, there is little evidence that terrorists and piracy syndicates are collaborating. The economic motivations for piracy (which depend for fulfilment on the stability of maritime trade) may be in direct conflict with the motivations of terrorists (i.e. in achieving maximum disruptive effects in connection with attacks). Second, some plausible forms of maritime terrorism (e.g., the sinking of a cargo ship in order to block a strategic lane of commerce) actually present a relatively low risk, in large part because the targeting of such attacks is inconsistent with the primary motivation for most terrorist groups (i.e. achieving maximum public attention through inflicted loss of life). Third, any effort to sink a cruise ship would need to overcome engineering designs intended to prevent catastrophic failure of a ship's hull. Experts believe that improvised explosive devices would have limited capability to cause such failure (Greenberg et al 2006: 10). These technical and theoretical assumptions remain largely irrelevant to the customer who perceives there simply to be a risk. Greenberg's study also considers the concept of civil liability and how this creates the prospect that independent commercial defendants (i.e. cruise shipping 
companies) will be held responsible for any damages caused by terrorist attacks. This gives a strong incentive for the private-sector prevention and mitigation efforts discussed in subsequent paragraphs. Yet a further recent development in the cruise market, most notably with cruise lines as venues for meetings and conferences (Ahmed, 2008) emphasised safety as one of the key selection criteria by meeting organisers. It is clear that the perception of potential conference organisers and cruise passengers is increasingly important as a workstream running alongside scenario planning research to assess the potential effects of terrorism on cruising. Yet the relationship between terrorism and tourist travel raises many conceptual issues to which attention now turns.

\section{Terrorism and Tourist Travel: Conceptual Issues.}

According to Henderson (2007: 68), terrorism is 'the use of terror and violence by individuals or groups outside legitimate structures and processes to achieve desired ends which are usually political in nature'. Barker (2003) adds a moral dimension to this definition noting that terrorist acts using violence against civilians in pursuit of political ends are considered to be 'morally wrong' within societies in which they take place. Introducing a moral argument raises a curious dichotomy in any definition of terrorism and terrorist activity. Terrorists often have a deep seated belief that what they are doing is morally justified (Whittaker, 2004). Differences in religious beliefs and social norms have all been used by terrorist groups to justify their course of action (i.e. they had no choice but to attack). Sonmez and Graefe (1998) regard this as somewhat of a cliché. Nanthanson (2010) has argued that because terrorists will always attack the innocent. Such an attack can never be considered to be morally right. Wilkinson (2006) agrees with this proposition, stating it is wrong to kill people for political ends without having political authority. Whittaker (2004), however, debates what is morally right and raises the question of whether terrorist activity could be seen as being morally justified if the consequences of such an attack are considered desirable. In doing so, this raises the deep philosophical question of what is desirable. There remains no definitive profile of a terrorist (Hogan, 2009). To attempt to construct such a profile would simplify a complex subject with a one size fits all approach. Gupta (2006) notes such a profile would invariably change according to group, country and culture.

Enders and Sandler (2006) provide a range of examples of how terrorists make a political statement. Typically these include capturing hostages, bombings, assassinations, threats and hoaxes, suicide attacks, sabotage and chemical or biological attacks. Such techniques have been used by a vast range of terrorist groups around the world including separatist, ethnocentric, nationalist, revolutionary, political, social and religious groups (Terrorism Research, 2011). Since the beginning of mass tourism in the 1950s, tourists have become highly visible targets for terrorists. As a result, terrorism and the threat of terrorism have created problems for the tourism industry; namely a fear and reluctance to travel (Bauman, 2007; Mansfield and Pizam, 2006; Pizam and Fleischer, 2002). However, one significant change in terrorist activity is that tourists are no longer innocent bystanders to such attacks. The current trend is for terrorists to deliberately target and attack tourists (Swarbrooke and Horner, 2004). Tourists are often referred to as 'soft targets' as they are easily identifiable, unarmed, vulnerable and in unfamiliar environments with foreign customs and language barriers (Kucukaltan, 2006). Sonmez and Graefe (1998) examine how tourists act as ambassadors for their country and, by attacking a tourist, a terrorist group is making a direct attack on that country. A terrorist attack can cause both disruptive and detrimental effects to a destination or mode of transport, especially if that country is dependent upon tourist spending (Tarlow, 2006a). Lepp and Gibson (2003) note that terrorists wishing to destroy a national economy will logically attack countries 
that have tourism as one of their main exports. The tourism industry prospers in democratic and liberal environments making it sensitive and vulnerable to external shocks. Changes in the desirability, reputation and market perception of the tourist product, for example, a destination or mode of transport can all have a negative impact on a destination or product image and appeal (Niininen and Gatsou, 2007). The perishability of the tourism product only adds to the tourism sector's vulnerability (Evans and Elphick, 2005). In developing countries these problems are compounded in that they take much longer to recover from a terrorist attack lacking the resources required to repair infrastructure and tourist facilities. Even a perceived risk of danger can be enough to prevent tourists from travelling to a destination or purchasing a particular product (Arana and Leon, 2008), such as a cruise holiday. Terrorists recognise this and aim to create a sense of fear among the travelling public (Kucukaltan, 2006). Fear can be transmitted instantly via technology platforms including television and the internet and Tarlow (2006a) notes the careful manipulation of the media as a key terrorist trait.

The defining terrorist attack of the twenty first century was September $11^{\text {th }} 2001$. Smith (2005) reports that this was the first hostile attack on mainland America by a foreign adversary since 1912 with many believing that it was an attack on American values. The events of that day altered people's perception of the measures terrorists would go to fight their cause (Nieder and Enos, 2002). Subsequent rhetoric has seen $9 / 11$ described as 'the day that changed the world' (Watson, 2009). Historically, terrorist incidents involving the maritime industry have been rare (Lorenz 2007, with the exception of the long history of piracy. However, Goodrich (2010) points out that the events of September $11^{\text {th }} 2001$ demonstrated how tools for commerce and leisure can be used as potential terrorist weapons highlighting the possibility of an attack in the maritime domain. Greenberg et al (2006: 85 ) has articulated the attractiveness of striking at a cruise ship by stating that 'there is the potential to kill large numbers of people and cause billions of dollars of economic damage as well as eliciting considerable media attention by attacking a highly visible symbolic target'.

Lorenz and Gaouette (2007) highlight the various ways cruise ships could be targeted for terrorist attack, as discussed earlier in Figure 2. These include hijacking, sinking a ship using an explosive device, a standoff attack and a biological attack on the ships food or water supply. While undertaking such an attack would require terrorists to acquire complex maritime skills including navigation, piloting and ship handling, Lorenz and Gaouette argue that the precise scheduling of cruise ship timetables allow terrorists to be aware of where any ship is at any moment in time together with its next port of call. Such information would assist the planning of any such attack. Bohn (2004) acknowledged that the last successful terrorist attack on a cruise ship was in 1985 when an Italian vessel the Achille Lauro was hijacked by a group of terrorists from the Palestine Liberation Organisation. Terrorist groups have shown interest in targeting the cruise shipping industry (Gaouette, 2010) as well as two maritime vessels including the US Navy ship USS Cole in 2000 and the French Oil Tanker MV Limburg in 2002. As cruise shipping companies continually look to expand their destination portfolios it is inevitable that they will find themselves in more 'hostile' or dangerous shipping lanes (Koknar 2004). These include the Malacca Straits, Suez Canal and parts of Indonesia and East Africa. Piracy, a form of maritime terrorism, has proved to be a problem for cruise ships sailing off the coast of Somalia as evidenced by an attack on the vessel Seabourn Spirit in 2005. In order to allay customer fears, the travel industry has made concerted attempts to improve passenger safety. In the aviation sector, governments moved quickly to restore consumer confidence by introducing a range of measures after $9 / 11$ including the installation of explosive detection equipment at airports the use of full body scanners and refining passenger profiling systems (see Figure 3). 
Figure 3 International efforts aimed at improving aviation security.

Installation of explosive detection

equipment at airports

Full body scanners

Refining passenger profiling systems

Testing more baggage

for trace explosives

Improving security training for airport staff

Improving airport security

at perimeter level
Increase in the use of air marshals

More passenger searches by hand

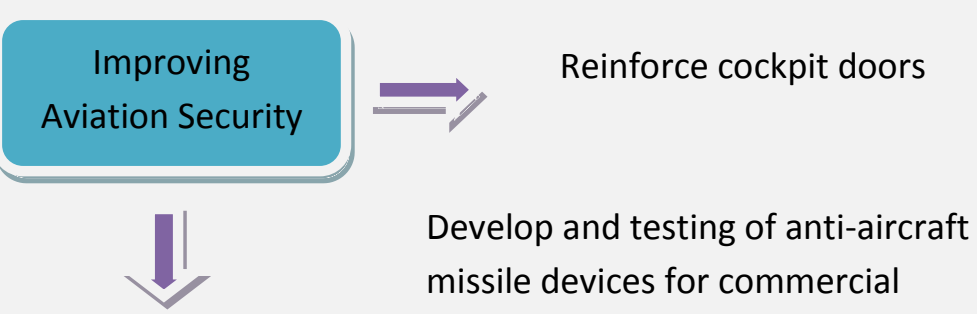

Wider use of sniffer dogs

Source: Adapted from Price and Forrest (2009)

The 9/11 attacks highlighted the vulnerability of transport infrastructure to international terrorism. It also raised the awareness of a similar attack on the maritime industry (Vesky, 2008, Lorenz, 2007). In order to strengthen maritime security the International Maritime Organisation reviewed its International Convention of Safety of Life at Sea $(1974,1988)$ replacing it with a new International Ship and Port Security Code (2004). It has since been adopted by 108 countries and has helped to introduce uniform safety and security standards across the maritime industry (Tally, 2009). McNicholas (2008) notes all ships and ports are expected to provide:

- Company/Port security officers responsible for assessing the vulnerability and threat to ships and ports.

- Company/Port security plans.

- Annual audits of ship and port security measures.

- Staff training together with ship/port drills and exercises to be undertaken every three months.

- A continuous synopsis record including a permanent record of the ships operations movements and ownership.

- Ship security alert systems directed at informing land based authorities of any potential terrorist attacks, hijackings or acts of piracy.

Given the increasing level of concern about terrorist attacks in tourism, it is also pertinent to consider the wider literature on risk perception as the principal area in which this research is located because the risk perception is what influences consumer behaviour and shapes the decision to book and take a cruise.

\section{Risk perception of terrorism by tourists}

How tourists perceive risk is an important determinant of how terrorism impacts upon international travel (Laws and Prideaux, 2005). Fuchs and Reichel (2004) observe how the purchasing behaviour of tourists can 
be affected by the risks associated with travel to a particular destination or region but the link between risk perception and international tourism is relatively unexplored (Lepp and Gibson, 2003). Santana (2003: 304) suggests that 'perception is reality in the tourism industry'. This makes tourism extremely sensitive to perceived changes in risk and operating conditions. Laws et al (2007) concludes terrorism is one of the major risk factors that can affect the tourism industry alongside wars and political instability, health concerns, natural disasters and crime. Bourne (2010) and Cooper and Erfurt (2007) have argued that within these categories risk can be divided into high and low risk events. A natural disaster such as the Japanese earthquake and Tsunami of 2011 might be considered as being low risk as they occur relatively infrequently. However, as Pizam and Fleischer (2002) conclude it is the greater the frequency of terrorist attacks and not the level of severity that influences the extent of impact on tourist purchasing decisions. This might help to explain why destinations that have fallen victim to terrorism more than once are often slow to recover from such an event. (McKercher and Pine, 2004).

Fuchs and Reichel (2004) provide evidence to suggest that when a consumer experiences risk they will adapt their purchasing behaviour in order to reduce risk to a 'tolerable level'. It is not inconceivable that any attack on a cruise ship or even a perceived threat could warrant a change in consumer attitude and a movement away from this form of holiday travel. How risk is perceived will clearly differ from person to person (Cooper et al, 2008). Lepp and Gibson (2003) and Fuchs and Reichel (2004) have also shown that it can be influenced by personality attributes, demographics and past tourist experience. The influence of destination image has been studied by Avraham (2006) who has shown that persistent negative images can have a cumulative impact on tourist destinations ultimately leading to the decision to switch destinations. In contrast, Beirman (2003) has considered the impact of government travel advisories concluding that their influence on tourism demand is inconclusive. What the published research demonstrates is the importance of examining various scenarios of terrorist attacks in new tourism settings such as a cruise ship, illustrates the need to be look much wider than the conventional focus on aviation and land-based transport.

\section{Rationale for Research}

In relation to scenario planning, it is the extent to which tourists perceive there to be a terrorist threat in an uncertain future, as further evidenced by the safety concerns following the Costa Concordia sinking in 2012 , that highlights the wider concerns associated with the safety and security of visitors. This is a subject that has received relatively scant attention in the research literature (Watson, 2009). Research has largely focused on the impact of terrorism on tourist destinations (Dixon and Kaganoff Stern, 2004; Smith 2009; Mansfield and Pizam, 2006) and on individual sectors of the travel industry, particularly aviation (Page, 2009; Price and Forrest, 2009). In contrast, this paper seeks to establish the extent to which cruise ship tourists perceive there to be a terrorist threat. It considers the consequences of any action on their purchasing behaviour and their image of the industry. These views are set alongside those of the cruise shipping industry and similarities and differences in perception are highlighted. Previous studies of tourist perception of risk (e.g. Laws and Prideaux, 2005) examine risk through primary research focused upon tourists as consumers so as to explore the complexities of their behaviour and this study is embedded in this approach to understand the implications of marine terrorism for cruise ship passengers and is informed by the scenario planning context developed by Greenberg et al (2006).

\section{Research Methodology}


To assess consumer risk and its relevance to consumer decision-making, this study undertook to focus on a range of stakeholders with interests in cruise tourism. Various data collection methods were considered to reach a target audience such as company client lists, web viewers of cruise reviews and other subscription/membership lists. It was recognised that access to actual cruise passengers was likely to be closely protected by cruise companies due to the sensitive nature of the topic. All the companies approached with a request for an interview, with the exception of one, declined to take part in the exercise. This is a common trait in studies of risk (Hoffman, 2006). Company contact lists including the International Cruise Shipping Directory proved useful in identifying possible representatives from companies to interview. Cruise ship reviews, such as those included in Cruise Industry News, provided useful secondary data to supplement and guide the collection of primary data. Subscription and membership lists taken from publications including Cruise Critic and Cruisejunkie were originally considered as a way of identifying a possible sample frame. This was subsequently rejected following concerns from the publishers as to the aims of the study. It was concluded the most convenient way of selecting a sample of potential cruise passengers was to target them at an event for cruise holidays at a major national venue. The aim of the survey was to examine themes identified in the scenario planning exercise by Greenberg et al (2006) and to frame the study in terms of the safety and security themes it raised. The focus on the UK, as a major source market for global cruise holidays was designed as an initial exploratory study which could be replicated in other worldwide locations at a later point in time.

Data was collected by means of a standardised site or user questionnaire conducted on visitors to the London Olympia Exhibition Centre, the venue for CRUISE, a dedicated 2-day cruise shipping exhibition sponsored by the UK national newspaper The Daily Telegraph, on the 26th March 2011. The study used a single interviewer-completion methodology in order to increase response rates, ensure fuller and more complete answers and to allow the interviewer to respond to any problems of misinterpretation on behalf of respondents. By giving responsibility for the collection of information to one individual consistency of delivery style was assured. Since the first staging of the event in 2009, CRUISE has attracted over 17,000 visitors per annum, $67 \%$ of whom state that cruising is their main form of holiday (The Daily Telegraph, 2010). The exhibition consequently provided an excellent opportunity to survey a small sample of the UK public who had either cruised in the past or who were interested in cruising in the future

In order to ascertain interviewee perceptions of terrorism and the terrorist threat, a combination of open-ended and closed questions were asked. Both sought to supplement existing secondary data and provide a new insight into customer perceptions of risk and the threat posed to cruise shipping. By adopting a face-to-face strategy for conducting research, immediate data information exchange was elicited and, where appropriate, the interviewer was able to get respondents to develop and clarify their answers The questionnaire was sub-divided into three sections - cruise line security; the cruise shipping industry and terrorism; and customer experience of cruise shipping and the demographic profile of respondents. Questions on cruise line security sought to investigate customer perceptions of safety within the cruise shipping industry by asking a series of questions relating to current safety measures, security measures they would like to see in place, threats to cruise ships and risk, which was congruent with the study of risk by Greenberg et al (2006). Again, these questions were closely related to the issues raised by Greenberg et al (2006) in their scenario planning exercise, albeit in a supply context (i.e. cruise ship focused), whereas this study sought to validate the consumer perspective of a 
future terrorist attack and its likely impact on visitor perception and potential behaviour change. The questionnaire sought to ascertain participant opinions on the likely threat of a terrorist attack on a cruise ship and whether any such attack would affect their image of cruising and their likelihood to purchase a cruise holiday. A series of demographic questions sought to establish whether perceptions were influenced by age and sex. Whether attitudes were determined by cruise ship experience was established by asking interviewees if they had previously undertaken a cruise. A variety of question styles were used in this study. These included the use of Likert scales designed to establish the extent to which respondents agreed or disagreed with a question or statement; numerical responses whereby respondents chose from various adjectives (for example low moderate and high risk); and checklists simply requiring respondents to choose from a predetermined list of answers. The advantage of all of these question types was that responses could be quantified. Where a supplementary non-elicited response was given this data was could be further used to clarify answers. The questionnaire was piloted in the week prior to the Exhibition with twenty employees linked to a well-known travel wholesaler. This was done in order to identify any potential ambiguity in questionnaire design and test that the research questions and elicited responses were congruent with the aims of the study. Ten employees were randomly chosen for their cruise ship experience while ten were selected on the basis that they had never cruised before. This ensured that all questions could be understood by potential interviewees irrespective of their background experience of cruise shipping.

The Exhibition allowed an excellent opportunity to question any individual with an interest or experience in cruise shipping in one specific place at one particular time. In total 144 responses were obtained from face-to-face interviews. This represented the maximum number that could be interviewed in a day and a sample size large enough for statistical inference. A non-probability sampling technique was used i.e. convenience sampling. Finn, Eliott-White and Walton (2000) note non-probability samples are common where individuals are interviewed at source such as a visitor attraction or special event. Zikmund (1997) and Brewster and Hunter (1989) maintain that it is possibly the most widely used sampling strategy and when used for exploratory purposes results can be quite valid. While probability sampling remains theoretically the preferred technique for reasons associated with precision and confidence (Veal, 2006) Finn et al (2000) do not preclude the use of various analytical techniques based on this sampling strategy. Indeed Dimmock (1999) concludes that with exploratory work which includes elements of a qualitative approach, and where there are limitations of time, cost and length, certain restrictions have to be imposed in the collection of data. As certain variables were regarded as central to the study (e.g. age, sex and whether the respondent had ever cruised before), an effort was made to survey equal numbers of males and females and experienced and inexperienced cruise passengers to capture a representative sample with these elements incorporated. These were selected from a variety of different predetermined age categories using Yarnal, Kersetter and Yen's (2005) profile of typical cruise ship passengers. Stratifying data collection for the purpose of subsequent data analysis remains a technique widely used in market research (Brase, 2009). To further explore the issues identified in terms of cruise line security a qualitative approach was chosen focusing on a structured interview with a Director from a leading cruise ship operator. For public relations and legal reasons this person wished to remain anonymous. This method was chosen as Veal (2006: 199) notes 'it can allow more sophisticated and detailed discussion of complex issues by probing more deeply than is possible with a questionnaire-based interview. Through sensitive questioning the interviewer can elicit credible, transferable and dependable results'. A series of carefully planned formal questions were prepared based on the existing literature and tourists' perception of the terrorist threat outlined at CRUISE. The thirty minute interview conducted in May 2011 centred on two lines of enquiry - the potential security threat to the cruise shipping industry posed by international terrorism and how any threat could affect the purchasing behaviour of the cruising pubic. In answering the former, the strategic response of cruise ship companies to minimising 
the terrorist threat (the ISPS code) was addressed. In the case of the latter a series of guarded suggestions were offered as to the likely repercussions of any incident on the industry as a whole.

\section{Data Analysis and Findings}

Data was analysed using two methods. Quantitative data collected by means of a customer questionnaire conducted at CRUISE 2011 was analysed using statistical data software (SPSS 18.0). A variety of different descriptive and analytical techniques were used to interpret this data. These included the use of measures of central tendency (descriptive statistics); chi square analysis used to demonstrate the significance or strength of the relationship between two or more nominal variables and cross tabulations, designed to examine the association between dependent and independent variables based on frequencies (analytical statistics). Qualitative data, collected by means of an interview with a senior cruise shipping employee, was subject to content analysis. Content analysis involves detailed analysis of the content of a certain body of literature or other documentary source, such as in this case a transcript of an interview with a Director from a leading cruise shipping company. Here the text becomes the focus of research in its own right rather than merely being a report of the research. Data was analysed adapted from a methodology developed by Mathews (1987) and Stevens (1997). Here the transcript was read and trends noted in relation to the four basic questions outlined below. Reference to each category was noted in the text and inferences drawn from the results. Where possible findings were linked to primary and existing secondary research

As noted in both instances the answer to four basic questions provided the framework for analysis:

do customers perceive the cruising to be a safe and secure form of holiday travel? do they perceive there to be a risk of attack from an international terrorist group?

$\square$ should a terrorist incident happen on any cruise ship would this put them off purchasing the product?

$\square$ what can be done to minimise the threat and make cruising safer?

Of the 144 questionnaires completed by visitors to CRUISE, 66 participants were male and 78 were female. Some 112 (or $78 \%$ ) of participants had cruised before, with 40 (27.7\%) having undertaken five or more cruise holidays. Respondents were generally well travelled with 54 (37.5\%) stating that they took three or more holidays per annum, which is indicative of more affluent travellers in a UK context

\subsection{Customer perceptions of safety and security on-board cruise ships}

Evans and Elphick (2005) and Page et al (2010) argue that the travel and tourism industry is highly susceptible to external shocks and the perishability of the tourism product can leave it vulnerable and exposed in a crisis illustrating the growing interest in emergency planning within the sector. Arguably one of the reasons for growth in the cruise shipping industry over the past two decades has been because it has been viewed by customers as a safe and low risk holiday option (Dowling, 2006). While certain tourist destinations and other transport modes have suffered from political instability, crime, war or acts of terrorism, cruise shipping has remained remarkably free from any such incidents (Lepp and Gibson, 2003). Questionnaire respondents were asked to what extent they agreed with Dowling's (2006: 427) statement that 'safety and security are a hallmark of cruising' (Table 2). Nearly half of those questioned (70 
individuals or 49\%) said they 'strongly agreed'. A further 46 (or 32\%) stated that they 'agreed'. In both instances 48 (or $33 \%$ ) of respondents indicated that they had cruised before.

Table 2. Perceptions of safety and security of cruising

\begin{tabular}{|l|l|l|}
\hline & \multicolumn{2}{l|}{$\begin{array}{l}\text { To what extent do you agree with the following statement: "safety and } \\
\text { security are a hallmark of cruising"? }\end{array}$} \\
\hline & \multicolumn{1}{|c|}{ Responses } & \multicolumn{1}{c|}{ Percentage } \\
\hline Strongly agree & 70 & $49 \%$ \\
\hline Agree & 46 & $32 \%$ \\
\hline Neither agree nor disagree & 22 & $15 \%$ \\
\hline Disagree & 6 & $4 \%$ \\
\hline Strongly disagree & 0 & $0 \%$ \\
\hline Total & $\mathbf{1 4 4}$ & $\mathbf{1 0 0 \%}$ \\
\hline
\end{tabular}

The strength of the relationship between safety and security as a hallmark of cruising and cruise experience was tested by means of a chi-square analysis. This indicated that there was a relationship between cruise experience and perceptions of safety (X2=0.040, DF12, significant at the $5 \%$ level). The overall impression of potential cruise ship customers that cruising was a safe and secure activity were echoed by that of the Director of a leading cruise shipping company who stated that they 'completely agreed' with the statement and that the 'safety and security of passengers and crew were the company's ultimate concern and guided all operational decisions'. Unlike the aviation sector, cruise shipping has not had to deal with any serious incidents involving terrorist activity or technical failure resulting in a serious loss of life. Ward (2010) reported that the cruise shipping industry enjoyed the best safety record with less than twenty fatalities in the last twenty years, although this has now increased due to recent events. Nevertheless, the repercussions of an event such as a terrorist attack could prove even more acute due to the rarity of such an incident. After 9/11, a range of new security legislation was introduced across all sectors of the travel and tourism industry. The cruise shipping industry's response was to introduce the ISPS code in 2004. Whether enhanced security legislation translates into cruise ship passengers feeling more secure was examined in the questionnaire survey (Table 3).

Table 3: The relationship between cruise experience and perceptions of adequacy of security measures

\begin{tabular}{|l|l|l|l|l|l|}
\hline \multirow{2}{|c|}{} & \multicolumn{4}{|l|}{$\begin{array}{l}\text { Do you think the security measures cruise lines currently } \\
\text { have in place are adequate? }\end{array}$} \\
\cline { 2 - 6 } & Yes & No & Don't know & Total \\
\hline \multirow{3}{*}{ Have you cruised before? } & Yes & 86 & 8 & 18 & $\mathbf{1 1 2}$ \\
\cline { 2 - 6 } & No & 4 & 8 & 20 & 32 \\
\cline { 2 - 6 } & Total & $\mathbf{9 0}$ & $\mathbf{1 6}$ & $\mathbf{3 8}$ & $\mathbf{1 4 4}$ \\
\hline
\end{tabular}

The majority ( 90 or $63 \%$ ) of questionnaire respondents stated that they thought that security measures were adequate. Only $16(11 \%)$ considered they were not. The strength of the relationship between the level of cruise experience and customer perception of the adequacy of safety and security was again tested by means of a chi-square analysis. This illustrated a significant relationship ( $X 2=0.218$, DF2, significant at the $5 \%$ level) indicating the more a person had cruised the more likely they were to feel that safety and security measures were adequate, reflecting a confirmatory relationship often noted in the social 
psychology literature where repeat travel builds a notion of security, often in a similar setting or destination.

The survey then sought to establish whether tourist perceptions of cruise ship safety were age related. No significant relationship was found (X2=2.459, DF10, insignificant at the $5 \%$ level) (Table 4). A cruise ship holiday was perceived to be a safe and secure holiday irrespective of age.

Table 4: The relationship between age and perceptions of adequacy of security measures

\begin{tabular}{|l|l|l|l|l|l|}
\hline \multicolumn{2}{|c|}{} & \multicolumn{4}{l}{$\begin{array}{l}\text { Do you think the security measures cruise lines currently } \\
\text { have in place are adequate? }\end{array}$} \\
\cline { 2 - 6 } & Yes & No & Don't know & Total \\
\hline \multirow{3}{*}{ Age group } & Under 24 & 4 & 2 & 2 & $\mathbf{8}$ \\
\cline { 2 - 6 } & $25-34$ & 16 & 6 & 14 & $\mathbf{3 6}$ \\
\cline { 2 - 6 } & $35-44$ & 4 & 0 & 4 & $\mathbf{8}$ \\
\cline { 2 - 6 } & $45-54$ & 16 & 4 & 4 & $\mathbf{2 4}$ \\
\cline { 2 - 6 } & $55-64$ & 42 & 4 & 10 & $\mathbf{5 6}$ \\
\cline { 2 - 6 } & Over 65 & 8 & 0 & 4 & $\mathbf{1 2}$ \\
\cline { 2 - 6 } & Total & $\mathbf{9 0}$ & $\mathbf{1 6}$ & $\mathbf{3 8}$ & $\mathbf{1 4 4}$ \\
\hline
\end{tabular}

The most frequent response was that security measures currently in place were adequate. This did not prevent respondents commenting on additional measures they would like to see in operation in the cruise sector (Table 5). The most common measure cited was the need to introduce 'airline style' full body scanners for passengers seeking to board a ship and improve the screening of potential cruise line employees.

Table 5: Customer perceptions of the need to improve security measures within the cruise shipping industry.

\begin{tabular}{|c|c|c|}
\hline \multicolumn{3}{|c|}{$\begin{array}{l}\text { Indicate one potential security measure you would most like to see in operation within the cruise } \\
\text { shipping industry? }\end{array}$} \\
\hline The use of sniffer dogs at ports & 28 & $19 \%$ \\
\hline Searching more passengers by hand & 8 & $6 \%$ \\
\hline The use of full body scanners & 40 & $28 \%$ \\
\hline Improved security screening of cruise line employees & 32 & $22 \%$ \\
\hline Enhanced passenger identification screening & 26 & $18 \%$ \\
\hline More security guards onboard ships & 10 & $7 \%$ \\
\hline Total & 144 & $100 \%$ \\
\hline
\end{tabular}

Technology and the use of full body scanners is currently being trialled or introduced across the aviation industry as a way of combating terrorism and preventing passengers smuggling illegal items onto aircraft. Currently it is a technology relatively underutilised in maritime security (Stratton, 2010). Criticisms of the technology have centred on the graphic nature of the images produced and the levels of radiation they emit (Warren, 2010; Mercola, 2011). Viable alternatives, such as introducing more security guards on ships and increasing the security presence, appear generally unpopular with passengers who see them as an 
inappropriate intrusion and unappealing in a holiday environment within what is a confined space. The latter point was highlighted in interview with the Director of a cruise shipping company. It was noted they 'would resist any heightened procedures that impacted on the satisfaction of guests'. While the cruise shipping industry appears eager to promote the security measures and to comply with legislation that has been put in place post 2001, it is clear that there is potentially some element of conflict between making sure passengers are safe and feel safe and implementing a full range of security procedures. Gaps in security do exist and the full range of ISPS measures demanded in 2004 has not always been implemented for cost, image or technical reasons (Gaouette, 2010).

\subsection{The perceived threat of a terrorist attack against a cruise ship.}

Cruise ships have steadily increased in size over the past two decades (Ward, 2010). The result is that ships of over 100,000 gross tonnes are not uncommon. As ships have increased in size, so have security concerns (Greenberg et al, 2006). Gaouette (2010) acknowledges that cruise ships, in catering for large numbers of passengers in a confined space, makes them an 'ideal' terrorist target. Both Gaouette and Greenberg note that any attack on the cruise shipping industry could be seen as a symbolic attack on the West as the largest cruise ship companies are American owned with cruise holidays typically being taken by Western tourists (even though the ownership is not always reflected in where they are registered). But while the ownership illustrates the iconic nature of cruise ships as symbols of conspicuous consumption, reminiscent of the age of cruising in the 1930s when this was the most luxurious mode of travel, the imagery now being promoted by cruise ship companies is highlighting a return to this luxury notion.

Henderson (2007) observes that the cruise shipping industry is vulnerable to many external threats, all of which can affect its operational efficiency. Foremost amongst these threats are political instability at port destinations, natural disasters and adverse weather conditions. However, visitors to CRUISE saw a potential terrorist attack as the major threat to cruise shipping companies (Figure 4). In highlighting such a response, respondents identified with the work of Rubacky (2010) who concluded that today one of the greatest threat to passengers and ships comes from terrorism

Figure 4 Customer perceptions of threats to the cruise shipping industry. 


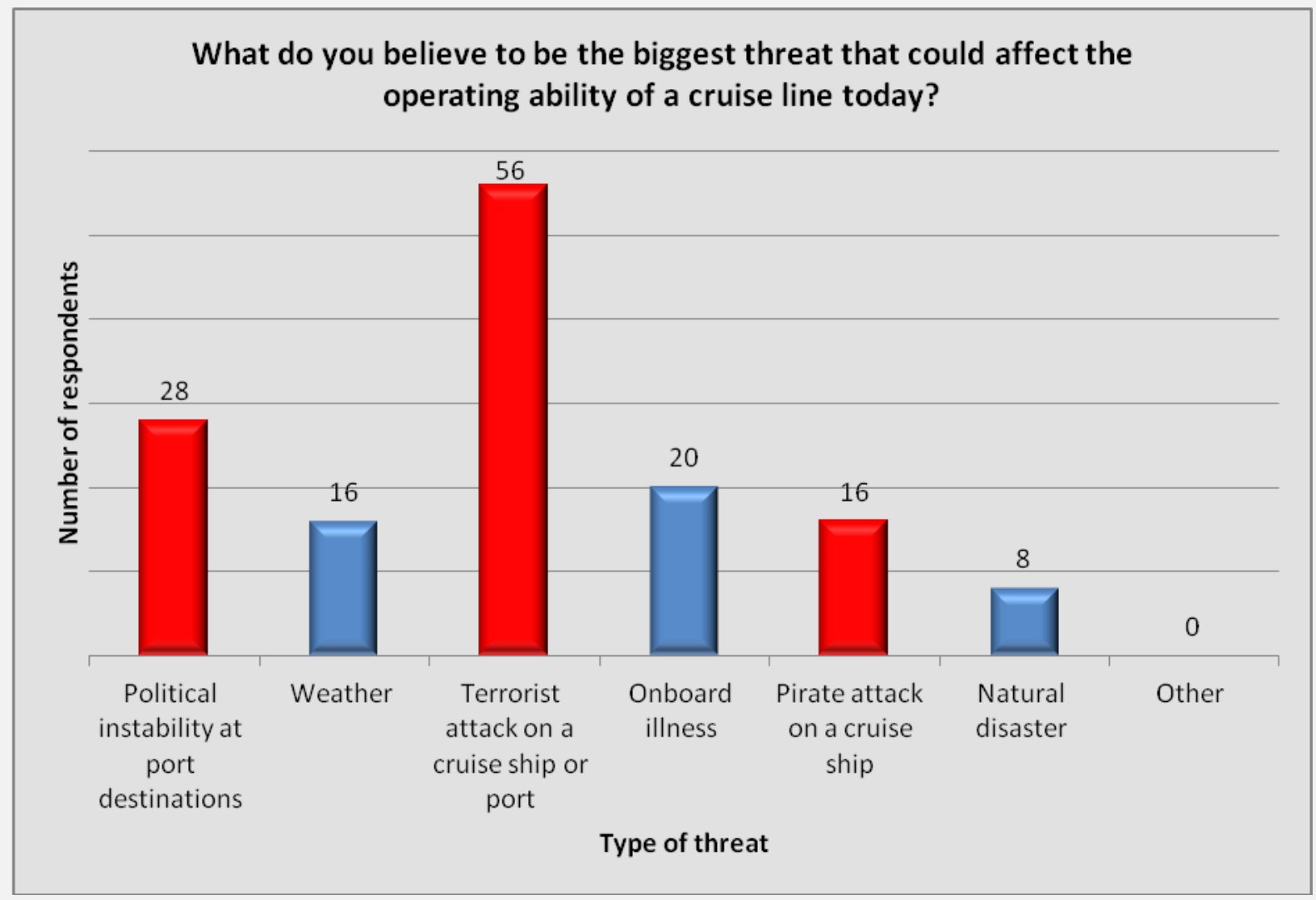

Respondents who identified a perceived terrorist threat were subsequently asked to identify the level of this threat by means of a likert scale question. This asked respondents to indicate on a scale between 'highly probable' and 'highly improbable' the extent of this threat. They were also asked to indicate the reasons for their response. Some 64 of the 144 questionnaire respondents (44\%) considered an attack on a cruise ship as 'probable'. In contrast, only 34 (23.5\%) considered it to be 'improbable' or 'highly improbable'. Despite having cruised before and being aware of safety procedures aboard cruise ships, the majority of respondents felt that an attack was 'probable' (48 or 33.3\%) (Table 6).

One might debate the extent to which a question that asks to what extent respondents perceive the threat of an attack on a cruise ship is deemed probable or improbable to be leading and potentially biasing responses. The question did however make the assumption that respondents were aware of the general high levels of security alert which the UK was experiencing at that time. Consequently, this was an issue that had been prominent in the media. Respondents also had the opportunity to not complete the question or to assess the highly improbable nature of such an event if it was deemed to be leading. If this question was unintentionally deemed to be misleading, the results certainly did not demonstrate a strong bias towards this being a major event that was going to occur. The findings were supported by Tarlow's (2006b) argument that tourists have now become familiar with travel destinations and tourist infrastructure being targeted by terrorists. With familiarity comes a resigned fatalism that, at some time, an attack on a destination or travel mode (such as a cruise ship) will become inevitable.

Table 6 The perceived threat of a terrorist attack and cruise experience

\begin{tabular}{|l|l|l|l|l|l|}
\hline \multirow{2}{*}{} & \multicolumn{4}{|l|}{ What do you perceive the current threat of an attack on a cruise ship to be? } \\
\cline { 2 - 5 } & $\begin{array}{l}\text { Highly } \\
\text { probable }\end{array}$ & Probable & $\begin{array}{l}\text { Neither } \\
\text { probable nor } \\
\text { improbable }\end{array}$ & $\begin{array}{l}\text { Improbable } \\
\text { Highly } \\
\text { improbable }\end{array}$ & \begin{tabular}{l} 
Total \\
\hline
\end{tabular} \\
\hline
\end{tabular}




\begin{tabular}{|l|l|l|l|l|l|l|l|}
\hline \multirow{2}{*}{$\begin{array}{l}\text { Have you cruised } \\
\text { before? }\end{array}$} & Yes & 2 & 48 & 36 & 20 & 6 & $\mathbf{1 1 2}$ \\
\cline { 2 - 8 } & No & 0 & 16 & 8 & 6 & 2 & $\mathbf{3 2}$ \\
\cline { 2 - 8 } & Total & $\mathbf{2}$ & $\mathbf{6 4}$ & $\mathbf{4 4}$ & $\mathbf{2 6}$ & $\mathbf{8}$ & $\mathbf{1 4 4}$ \\
\hline
\end{tabular}

Questionnaire respondents were asked why they felt an attack on a cruise ship might be likely following up on the comments of those respondents who had noted the probable nature of such an event in the future. Figure 5 illustrates a number of these responses allowing for a free flow of comments. Respondent views were varied, but reflected perspectives outlined in the existing literature (Klein, 2002; Earnest,2003; Greenberg et al, 2006; Hall 2009) relating to probability and perceived risk as well as potential security weaknesses.

Figure $\mathbf{5}$ The reasons why an attack on a cruise ship is likely

"With the growth of terrorist attacks and pirate attacks it's much more likely then 10 15 years ago".

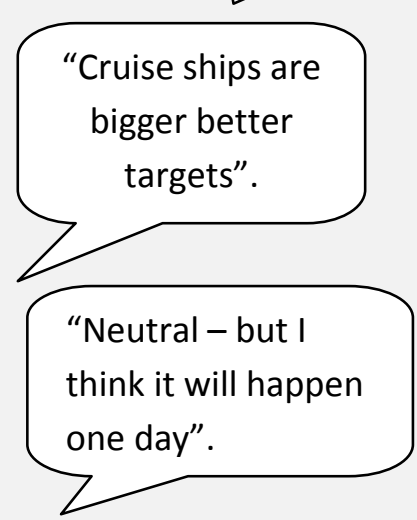

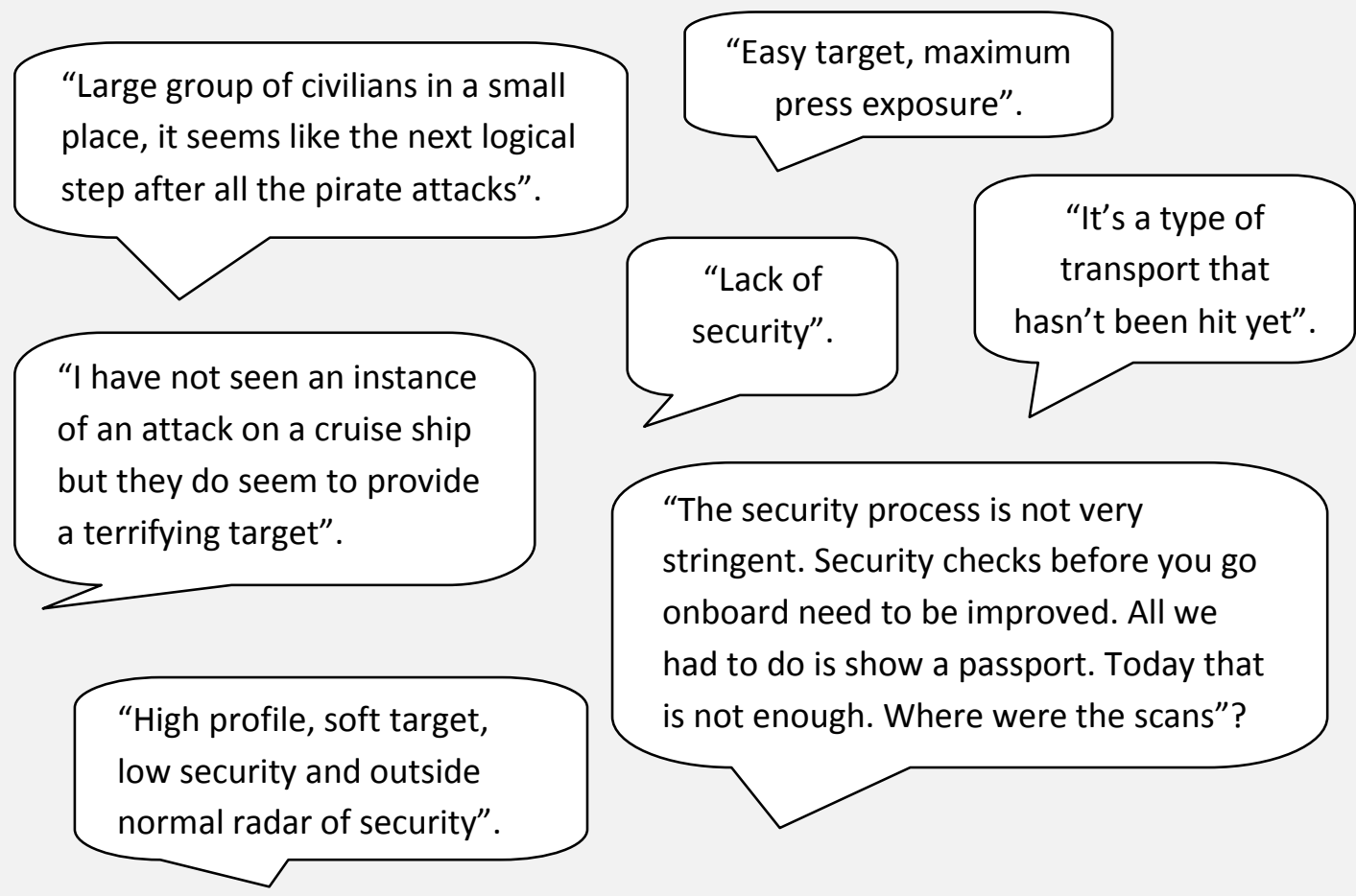

The spokesperson for the cruise shipping industry recognised that there was a risk and that the threat of an attack on a cruise ship had increased in recent years. 'Of course there is always a risk. We also live in an increasingly unsafe world'. Perhaps not surprisingly the company represented was not prepared to accept any such attack on their ships as a possibility arguing that their terrorism mitigation measures were more than adequate to address any such eventuality:

'Safety and security is paramount. I honestly believe our systems are second to none and can guarantee a safe and secure cruising experience. Every time a guest or crew member gets on or off a ship they pass through a number of stringent security checks. We use a sea pass card that has to match completely with our computerised records. Behind the scenes bags are scanned and passport details are matched to (US) security records. Onboard we have designated several people 
with responsibility for passenger safety. Let's just say we have learnt from our colleagues in the aviation industry here'.

Whether such opinions represent bravado or can be interpreted as the 'corporate view' is open for debate. It seems almost impossible for any cruise shipping company to guarantee the safety and security of their passengers. While not being dismissive of the concerns of potential passengers, it is clear that the latter do perceive there to be a very real risk from terrorist attack, as a gap between the operational procedures and traveller perception exists. The issue is whether this gap will develop into a gulf and act as constraint on further growth in the cruise market.

The CRUISE questionnaire sought to establish whether potential cruise ship passengers perceived there to be a greater risk travelling with particular cruise ship companies. Respondents were given a list of cruise ship operators and asked to identify which ones they thought were most at risk. Here the assumption was made that companies associated with the United States and its allies were seen as particularly vulnerable to attack. However, some 36 (or 25\%) respondents felt no one particular cruise line was vulnerable. These were invariably individuals who regarded an attack on a cruise ship to be improbable or highly improbable. This was also a view shared by the Director of the leading cruise ship company interviewed as part of this research. The remaining respondents recognised there was a risk; in some cases to more than one cruise line. In addition, it is important to note that in relation to growing acts of piracy, the geographical zones in which shipping (especially cruise lines) has expanded from the coast of Somalia to the wider Indian Ocean and farther afield.

\subsection{Risk Perception and Customer Purchasing Decisions}

To assess the effect and impact of risk perception on consumer purchasing behaviour, respondents were asked to rate their perception of risk. This was a view expressed both by 'experienced' and 'first time' cruise passengers (Table 7).

Table 7 Customer perception of the risk associated with taking a cruise holiday.

\begin{tabular}{|l|l|l|l|l|l|}
\hline \multicolumn{2}{|c|}{} & \multicolumn{5}{|c|}{ Perceived level of risk } \\
\cline { 3 - 7 } \multicolumn{2}{|c|}{} & 1 (Low) & 2 (Medium) & 3 (High) & Total \\
\hline \multirow{2}{*}{$\begin{array}{l}\text { Have you cruised } \\
\text { before? }\end{array}$} & Yes & 60 & 22 & 30 & $\mathbf{1 1 2}$ \\
\cline { 2 - 6 } & No & 12 & 16 & 4 & $\mathbf{3 2}$ \\
\cline { 2 - 6 } & Total & $\mathbf{7 2}$ & $\mathbf{3 8}$ & $\mathbf{3 4}$ & $\mathbf{1 4 4}$ \\
\hline
\end{tabular}

Given this perception, there is no reason to believe that potential risk has adversely affected the propensity of passengers to take cruises. However, previous experience has shown that a crisis, such as a terrorist attack, can result in a serious loss of confidence in safety and security measures adopted by the tourism industry culminating in a decline in visitor numbers and the consequent loss of tourist revenue (Laws and Prideaux, 2005). The survey data reported here would suggest that a similar attack on a cruise ship would have an identical response (Sonmez, Apostolopoulos and Tarlow, 1999). Nevertheless, passenger opinion was divided on this issue (Table 8). While 56 of the potential cruise passengers interviewed at CRUISE said that an attack on the cruise shipping industry would affect their decision to take 
a cruise holiday; 54 said that it would not with 34 suggesting 'maybe'. No significant differences were found in tourist perception between males and females on this issue. (X2 $=1.85$, DF2, Insignificant at the $10 \%$ level).

Table 8 The impact of a terrorist attack on customer purchasing decisions

\begin{tabular}{|c|c|c|c|c|c|}
\hline & & Yes & No & Maybe & Total \\
\hline \multirow[t]{3}{*}{ GENDER } & Male & 22 & 26 & 16 & 66 \\
\hline & Female & 34 & 28 & 16 & 78 \\
\hline & Total & 56 & 54 & 34 & 144 \\
\hline
\end{tabular}

Among potential cruise ship passengers expressing concern over an attack, the common strategic response was to suggest a decision either to cancel their holiday (47\%) or defer their booking (53\%). Among those passengers who suggested that they would probably defer any decision to book a cruise more than one third suggested that they would be prepared to wait up to one year before making any decision with another third suggesting such a decision would be deferred for at least a year (Figure 6) which is not dissimilar to other studies of the destination recovery cycle.

Figure 6: The length of time potential passengers would refrain from booking/taking a cruise holiday following a terrorist attack

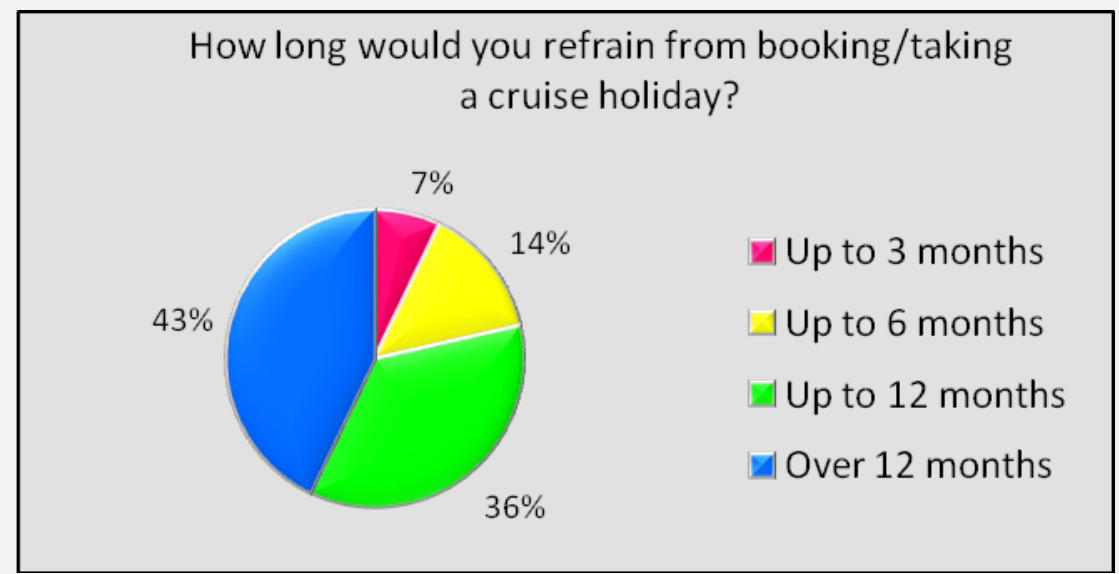

Assuming that any attack on a cruise ship might be expected to result in a reduction in bookings in the cruise shipping industry, it was expected that any such incident and consequent decline in passenger confidence would be of concern to company strategists. In the course of this research, an interview with a Director of a leading cruise shipping company somewhat surprisingly revealed while they recognised such an incident 
'without doubt would be the worst thing that could happen to this industry; a year is a relatively short time'. The respondent went on to state 'companies such as ourselves could be considered to be better protected from the potential repercussions of a terrorist attack due to our multinational product portfolio. As an American company I believe our US shareholders would not 'allow' us to fail as this would give terrorists a propaganda victory. Bankruptcy would also be undesirable for our creditors due to the vast amounts of money involved. My personal view is that any downturn in the market is more likely to affect small niche operators reliant on continuous cash flow. These companies would also take longer to recover due to their small customer base and limited appeal'.

Pizam and Fleischer (2002) have argued that it is the frequency of terrorist attack rather than the severity of any attack that has the greatest impact on tourist flows concluding that 'tourist destinations can recover from even severe acts of terrorism, as long as terrorist attacks are not repeated' (Pizam and Fleischer, 2002: 337). It is debatable whether in the cruise shipping industry 'one terrorist attack would be enough' to severely dent consumer confidence, possibly to the point of no recovery for certain companies. Tally (2009) suggests that it could. Both Meikle (2010) and Thomson and Martin (2010) also draw comparisons with that of the Concorde crash of 2000. Some 113 fatalities left the reputation of the airline damaged to the extent that British Airways and Air France were both forced to suspend services in 2003.

Given customer perception of risk and the likely impact of any terrorist related incident, the cruise shipping industry continues to pursue a policy of growth (Ruggero, 2011). Between May 2011-2012 sixteen ships were scheduled for launch adding a total of 39,995 passenger berths to current capacity. Any significant downturn in passenger numbers caused by a terrorist related incident could leave cruise shipping companies with excess capacity to fill. Such a situation would be compounded by the fact that cruise fares are often loss leaders with the majority of company profits coming from onboard expenditure (Klein, 2005). Despite growth in the European market, North America continues to be the cruise shipping industry's largest source market. Were terrorists to strike the cruise shipping industry, how the American market reacts to the attack would have a fundamental impact on the industry overall recovery. As McKercher and Pine (2005:107) note recovery cannot begin after a crisis 'until or unless the source markets begin to travel again'. Post 9/11 the propensity for Americans to travel internationally was significantly reduced. Many chose not to travel or avoided flying and Timothy (2010) commented on the wariness of Americans to travel outside the security of their homeland. Should an attack on an American cruise shipping company materialise, or such an attack take place in American territorial waters, it seems highly probable that this would be met by a reduction in the numbers of Americans either purchasing a cruising holiday or using maritime vessels as their principal transport mode.

\subsection{What can be done to minimise the threat and make cruise shipping safer?}

Potential cruise ship passengers interviewed at CRUISE 2011 were generally of the opinion that cruise ship safety and security procedures were adequate (Table 4) but highlighted a range of additional security measures that they would like to see introduced (Table 6). These were thought to increase confidence and reassure passengers that 'safety and security are the hallmark of cruising' (Table 3). Measures aimed at minimising risk can be grouped into two categories; portside initiatives and onboard strategies. Price and Forrest (2009) catalogue a range of measures that have been pioneered in the aviation industry aimed at reducing the risk of terrorist attack. The success of these measures is reflected in the absence of a major terrorist related incident on the ground or in the air since 9/11. Many of the initiatives discussed by Price 
and Forrest have become standard operating practice at airports. These include the use of explosive detection equipment, sniffer dogs, body scanners, passenger profiling, body searches, luggage restrictions and controlled access to parts of airport for the non-travelling public. The introduction of comparable measures at dedicated cruise shipping terminals has been advocated by Stratton (2010) whilst the use of reinforced cockpit doors separating pilots from their passengers, improved security training for airline crews and even the use of security guards (Air Marshalls in the United States) has become de-rigeur on many airlines (Mercola, 2011). Yet many of these measures to address the risk of terrorist attack do not easily translate across to the cruise shipping context. This is because a significantly enhanced security presence aboard ships would generally be seen as unpopular with both passengers and cruise ship companies. Only $7 \%$ of those interviewed at CRUISE welcomed such an initiative. The representative from the cruise industry also commented their company would 'resist any procedures that impacted on the satisfaction of guests'. A visible security presence was considered to be 'generally unpopular and not appealing in a holiday environment'. The cruise shipping industry is naturally eager to promote the security measures that have been put in place. However, the global nature of the industry presents logistical difficulties in making sure all safety legislation is enforced consistently in time and space. Anecdotal evidence (e.g. Gaouette, 2010) has highlighted major breaches of security including unplugged metal detectors, trucks with Arab licence plates parked adjacent to ships and failure to $x$-ray hand luggage and baggage.

If cruise shipping companies are to reduce the terrorist threat and reassure their passengers there will be a need for them to introduce credible crisis management plans and adhere to the mandatory requirements for the security of ships and ports. The need for crisis management plans in the travel and tourism industry became evident following a series of terrorist attacks and cruise related health issues such as pandemic flu. Santana (2003) has sought to outline what a crisis management plan should entail which is part of the wider development of business continuity and emergency planning, equating this to a series of planning and training activities designed to understand, prevent and manage a potential crisis. Skinner and Mersham (2002) discuss the benefits to companies of undertaking such an exercise, noting that such plans can help in identifying possible crises, crisis prevention, reducing response time and limiting the financial costs associated with dealing with the crisis. Strafford, Yu and Kobina Armoo (2006) also believe that crisis management practices can limit negative publicity and in turn lessen damage to a country's or company public image. Despite the obvious benefits of introducing crisis management plans, Sharpley (2005) maintains that they remain peripheral to the core activities of most company's operations. Indeed, many such plans are reactive rather than proactive in that they are produced after the event (Sanatana, 2003; Sonmez et al, 1999). Where crisis management plans have been overlooked key staff and decision makers are left technically emotionally and psychologically unprepared (Sanatana, 2003). This in turn only increases the intensity of the crisis (Skinner and Mersham, 2002). The secret is to be prepared for all eventualities including events that have not previously been faced such as a possible attack on a cruise ship (Pforr and Hosie, 2007).

This research indicated that one of the largest cruise shipping companies in the world had a crisis management plan and that they were prepared for a possible attack on one of their ships. In an interview with their Director they commented 
'Yes we have a crisis management plan. We would be foolish not to. At any one time we have 33 ships sailing around the world. Anything could happen. While we do not expect a major incident, you must always plan for the worst case scenario - even a terrorist attack'.

For security reasons the Director was reluctant to go into any detail on the nature of such a plan suffice to note that

'security and risk assessment is the responsibility of a dedicated team of individuals based in our American head office. These people devise emergency situations and practice drills. They go on continuously on our ships and in port. I am tempted to say $99 \%$ of our passengers are none the wiser and we would wish to keep it this way. Suffice to say we would seek to reassure our passengers that their safety and security is our ultimate priority'.

Clearly this is only one response from an industry that remains highly secretive and protects commercially sensitive data from its competitors. As such it can be questioned as to whether this view is representative of all large cruise ship organisations. It does, however, indicate that such organisations are aware of the importance of crisis management and have detailed plans in place to prepare for such eventualities.

The ultimate test of any cruise shipping company's crisis management plan will be its ability to understand and to handle a crisis situation and be able to continue to operate and function during a crisis (Mitroff, 2004). Mitroff (2004) considers their ability to handle such a crisis is linked to their organisational culture. Companies that survive crises are proactive and are prepared for such an eventuality. Such companies have identified the possible crisis; put in place risk assessment, understand damage containment and business recovery mechanisms; have established a crisis leadership team; and identified a range of stakeholders likely to be directly and indirectly involved in the execution of the plan. These activities would normally be expected to be introduced before, during and after any potential crisis. While some cruise shipping companies have plans in place and are well prepared for any such eventuality both in terms of the execution of a plan and in terms of the consequences to their business of an event, the real test is when it is put into practice demonstrating if it is simple to implement and manage. However, while it is always possible to simulate a crisis, Faulkner (2001: 145) notes that 'planning simulations do not always match the complex reality of everyday existence'. Whether all cruise shipping companies rigidly adhere to the mandatory requirements for the security of ships and ports appears more problematic. The International Maritime Organisation deemed it necessary to strengthen maritime security in a bid to lower the threat of a terrorist attack on its member's facilities. Old codes were re-examined (the International Convention of Safety and Life at Sea 1974 \& 1988) and were replaced in 2004 with the International Ship and Port Security Code (ISPSC). This has subsequently been adopted by 108 countries. The code is split into two parts. Part A provides the mandatory requirements for the security of ships and ports. Part B provides recommendations for implementation. The ISPS code applies to all ships on international voyages of more than 500 tonnes and the ports that cater to these ships. The code requires governments cruise lines, shipping companies and ports to detect and assess security threats and have in place plans designed to mitigate and respond to such threats.

While recognising that there is a potential terrorist threat, albeit a small one (Figure 4), no potential cruise ship passengers visiting CRUISE mentioned the need for cruise shipping companies to fully implement the ISPS code. Indeed, no passing reference to any aspect of the code was mentioned at all and perhaps it is not realistic to expect passengers to be conversant with such a code. However, if passengers were aware 
that cruise shipping companies were required to undertake regular audits of their security arrangements, they may respond in a different manner. It is clear that respondents do not recognise that cruise ship companies employ dedicated security officers with responsibility for assessing the security threat, while ships and ports are expected to produce detailed security plans outlining how they would respond to a crisis such as a terrorist attack, some of the anxiety expressed by respondents about potential risks while on a cruise might be overcome. This is all about communication and reassurance, a key feature of crisis management.

Possibly of more concern is the general lack of awareness in the cruise shipping industry of the statutory duties required to be addressed in the ISPS code. The senior representative from the cruise shipping industry interviewed in this research was not able to comment on the code, nor identify anyone based in their European headquarters that could. However the respondent noted, 'that's the responsibility of a small team of individuals based in Miami. As such, it's very difficult for me to comment on this. Very few people know the details of our security planning and I think its best kept that way'. Arguably passengers do have the right to know what cruise shipping companies are doing to reduce the risk of a possible terrorist threat. It also sends out a message to extremist groups that cruise shipping companies are not only taking the threat seriously, but are also prepared for any eventuality. Without such reassurances passengers may well feel anxious and concerned (see Table 6, Figure 5). It also strikes at the very heart of the assumption that safety and security are the hallmarks of cruising.

\section{Conclusion}

This study has shown that marine terrorism is a largely neglected theme in tourism research despite the growing significance of the global cruise shipping industry. Whilst the research by Greenberg et al (2006) has identified different attack scenarios for cruise ships, this research has extended the development of these scenarios to test the consumer perception of risk associated with these potential maritime terrorist events. While several potential types of risk can be identified, the greatest risk was thought to come from a terrorist attack on a ship or a port by an extremist group. The level of risk was thought to be low. This was because passengers had confidence in the safety and security measures adopted by the cruise ship companies. In fact, safety and security was seen as the 'hallmark' of cruising, an attitude expressed most frequently by experienced cruise ship passengers. While passengers appeared generally resigned to the fact that risk is associated with travel in the twenty first century, this did not necessarily mean that cruise shipping companies should ignore risk or play down the likelihood of an attack on one of their vessels. The survey indicated that passengers considered risk to be a serious issue to the point that they believed safety and security measures both aboard ships and in ports could and should be improved. The cruise shipping industry recognises that any attack on a vessel would have devastating consequences for their business. It would result in a reduction in passenger confidence culminating in a drop in bookings. The severity of such an impact would, in all probability, reflect the nature and scale of such an attack. Simultaneous attacks on several vessels would intensify concern and could cause passengers to cancel trips or delay the booking of a cruise holiday. For smaller cruise shipping companies the prospect of a major reduction in passenger revenues could bring the whole viability of their business operations into question.

To what extent conclusions can be drawn from a relatively small sample size and an interview with only one (albeit a very senior member) of the cruise shipping industry is questionable. There is also no guarantee that should a similar exercise be replicated in other regions of the world similar perceptions 
would be revealed. Nevertheless the evidence from the UK market is compelling. What passengers need is reassurance that their safety and security is being treated seriously. This will require cruise shipping companies to maintain credible crisis management plans and adhere to the mandatory requirements for the security of ships and ports. While it is clear that many cruise shipping companies have made such provision, further work needs to be done to publicise their efforts. Business continuity and resilience planning requires organisations, such as the cruise ship companies, to not only constantly review their crisis plans but also to assess their own readiness for specific emergencies, a feature highlighted in the case of the Costa Concordia. Although this study has been exploratory in nature it has demonstrated a critical link between risk-terrorism and consumer behaviour and has identified the need for cruise shipping companies not only to understand their customers but also what can affect purchasing decisions. Here negative perceptions relating to risk can clearly influence the decision to purchase a cruise holiday and post crisis recovery.

Further suggestions for research might explore specific aspects of risk and how they are perceived by customers together with the strategic response of cruise shipping companies to crises. This research provided some evidence to suggest that customer perception of risk is influenced by ship and by cruise line. The suggestion that 'mega-ships', the high profile flagships of their parent companies, and cruise lines registered in North America were more vulnerable to attack is worthy of further investigation. This raises some interesting questions as to whether certain ships, companies and regions of the world are perceived by passengers to be 'safer' and if so could this offer certain competitive advantages to those companies and regions. Pforr and Hosie (2007) for example have been able to highlight how post 9/11 certain tourist destinations were able to capitalise on their geo-political distance from North America. While $44 \%$ of respondents felt an attack on a cruise ship was probable; 56\% thought it to be unlikely. Research might explore the reasons for such confidence including perceived improvements in operational security measures. While this research has centred on one risk scenario presented by Greenberg et al (2006) others might be considered. Henderson (2007) recognises how cruise ships are vulnerable to other 'external' security threats. These might be considered to be equally important risk factors. It also seems reasonable to suggest that some of these, including political instability and prevailing weather conditions, might vary in relative importance around the globe. While this research has concentrated on customer perception towards cruise shipping, the perception of customers to the risks attached to visiting certain ports is almost totally ignored in the literature. It is, however, an area recognised by the industry itself and is reflected in the decision of companies such as RCCL to request a naval escort in visiting certain middle-eastern destinations and the ISPS code to include port installations. The limitations of the cruise shipping industry in being able to deal with a crisis was tragically highlighted in the events surrounding the sinking of the Costa Concordia in January 2012. The incident raised serious questions as to the ability of Costa Cruise lines to prepare, prevent, implement and manage such an event. The sinking of the Costa Concordia has identified the need within the cruise shipping industry to identify an effective crisis management model and examine to what extent such a model might be capable of being utilised. Here the work of Jacques (2007) might provide an initial framework for research analysis. Despite maritime terrorism being a neglected area of research in tourism, the use of scenario research to understand potential threats to the cruise industry can and has been undertaken. Important conclusions can be drawn as to how potential customers perceive the threat to cruise shipping and given the risk what cruise ship operators might consider to be a reasonable strategic response. 


\section{Bibliography}

Adams, K M. (2006) Terror and Tourism: Charting the Ambivalent Allure of the Urban Jungle. In: Minca, C. and Oaks, T. (eds.) Travel in Paradox: Remapping Tourism. Lanham: Rowman and Littlefield Publishers.

Adams, M. and Reed, D. (2005) Difficult Times Have Battered Airlines. [Online]. Available at: http://www.usatoday.com/money/biztravel/2005-09-14-airline-bankruptcy-cover x.htm [Accessed: 28th March 2011].

Ahmed, F. (2008) Site selection criteria for meetings on cruise ships: The view of corporate meeting planners', Journal of Convention and Event Tourism 9 (1): 81-94.

Arnoldi, J. (2009) Risk. Cambridge: Polity Press.

Aschauer, W. (2010) Perceptions of Tourists at Risky Destinations: A Model of Psychological Influence Factors. Tourism Review, vol.65, issue 2, p. 4-20.

Avraham, E. (2006) Public Relations and Advertising Strategies for Managing Tourist Destination Image Crisis. In: Mansfeld, Y and Pizam, A. (eds.) Tourism, Security \& Safety: From Theory to Practice. Oxford: Butterworth-Heinemann.

Barker, J. (2003) The No Nonsense Guide to Terrorism. London: New Internationalist Publications.

Baumann, K. (2007) Red Sky in the Morning: The Nexus between International Maritime Piracy and Transnational Terrorism. In: Forest, J J. Terrorism and Insurgency in the $21^{\text {st }}$ Century: International Perspectives, Combating the Sources and Facilitators. New York: Praeger Security International.

Beirman, D. (2003) Restoring Tourism Destinations in Crisis. Oxon: CABI Publishing.

Birnie, P. (1987) Piracy: Past, present and future. Marine Policy 11 (3): 163-183.

Bohn, M K. (2004) The Achille Lauro Hijacking: Lessons in the Politics and Prejudice of Terrorism. Virginia: Brassey's INC.

Bourne, P A. (2010) Crime, Tourism and Trust in a Developing Country. Current Research Journal of Social Sciences, vol.2, issue 2, p.69-83 [Online]. Available at: http://maxwellsci.com/print/criss/v2-69-83.pdf [Accessed: 9th April 2011].

Brace, I. (2008) Questionnaire Design: How to Plan, Structure and Write Survey Material for Effective Market Research. $2^{\text {nd }}$ ed. London: Kogan Page.

Bradfield, R., Wright, G., Burt, G., Cairns, G. and van der Heijden, K. (2005) The Origins and Evolution of Scenario Techniques in Long Range Business Planning, Futures, 37: 795-812

Brewster, C and Hunter, J.E. (1989) The validity and utility of selection. Hospitality and Tourism Educator Vol. 4 No.3 pp38-43.

Cartwright, R. and Baird, C. (1999) The Development and Growth of the Cruise Industry. Oxford: Butterworth-Heinemann.

Cooper, M. and Erfurt, P. (2007) Tsunamis, Earthquakes, Volcanism and other problems: Disasters, Responses, and Japanese Tourism. In: Laws, E. and Prideaux, B. and Chon, K. (eds.) Crisis Management in Tourism. Oxon: CAB International. 
Cruise Critic (2011) P\&O Cruises Backs Flood Stricken Brisbane. [Online]. Available at:

http://www.cruisecritic.co.uk/blog/?p=2315 [Accessed: $25^{\text {th }}$ April 2011].

Cruise Critic UK (2010) Cruise Reviews \& News. [Online]. Available at: http://www.cruisecritic.co.uk [Accessed: $6^{\text {th }}$ October 2010].

Cruise International (2011) Cruise Lines Drop Egypt as Uncertainty Grows. [Online]. Available at: http://cruise-international.com/cruise-lines-drop-egypt-as-uncertainty-continues [Accessed: 21st May 2011].

Cruise Lines International Association (2010) The Overview: 2010 CLIA Cruise Market Overview. [Online]. Available at: http://www.cruising.org/sites/default/files/misc/2010FINALOV.pdf [Accessed: 18th May 2011].

Cruise Market Watch (2010) Growth. [Online]. Available at:

http://www.cruisemarketwatch.com/blog1/growth [Accessed: 3rd October 2010].

Dimmock, K. (1999) Management style and competitive strategies tourism firms in Northern Rivers. Tourism Management Vol. 20 pp323-39

Douglas, N. and Douglas, N. (2001) The Cruise Experience. In: Douglas, N. and Douglas, N. and Derrett, R. (eds.) Special Interest Tourism. Brisbane: John Wiley \& Sons.

Dowling, R. K. (2006b) Looking Ahead: The Future of Cruising. In: Dowling, R.K. (ed.) Cruise Ship Tourism. Oxon: CABI.

Dowling, R.K. (2006c) The Cruise Industry. In: Dowling, R.K. (ed.) Cruise Ship Tourism. Oxon: CABI.

Dowling, R.K. (ed.) (2006a) Cruise Ship Tourism. Oxfordshire: CABI.

Duiniker, P. and Greig, L. (2007) Scenario analysis in environmental impact assessment: Improving exploration of the future. Environmental Impact Assessment Review 27 (3): 206-219.

Earnest, J B. (2003) Attacks of Terror: Surviving the Unthinkable. Lincoln: iUniverse Inc.

Enders, W and Sandler, T. (2006) The Political Economy of Terrorism. New York: Cambridge University Press.

Evans, N. and Elphick, S. (2005) Models of Crisis Management: an Evaluation of their Value for Strategic Planning in the International Travel Industry. International Journal of Tourism Research, vol. 7, p. 135-150.

Faulkner, B. (2001) Towards a Framework for Disaster Management. Journal of Tourism Management, vol. 22, p.135-147].

Fearis, B. (2011) Cruise Line Adds Visit to Libya. [Online]. Available at:

http://www.travelmole.com/stories/1145894.php [Accessed: 14 February 2011].

Finn. M., Elliott-White. M and Walton, M (2000) Tourism and Leisure Research Methods. Data collection, analysis and interpretation. Pearson Education, Harlow, England

Forest, J J. (2007) Terrorism and Insurgency in the $21^{\text {st }}$ Century: International Perspectives, Combating the Sources and Facilitators. New York: Praeger Security International. 
Frittelli, J F. (2008) Maritime Security: Overview of Issues. In: Vesky, J P. (ed.) Port and Maritime Security. New York: Nova Science Publishers

Fuchs, G. and Reichel, A. (2004) Cultural Differences in Tourist Destination Risk Perception: An Exploratory Study. Tourism, vol. 52, issue 1, p.21-37.

Gaouette, M. (2010) Cruising for Trouble: Cruise Ships As Soft Targets for Pirates, Terrorists and Common Criminals. New York: Praeger.

Gibson, P. (2006) Cruise Operations Management. Oxford: Butterworth Heinemann.

Glaesser, D. (2003) Crisis Management in the Tourism Industry. Oxford: Butterworth-Heinemann.

Goodrich, J N. (2002) September 11, 2001 Attack on America: A Record of the Immediate Impacts and Reactions in the USA Travel and Tourism Industry. Tourism Management, vol. 23, p.573-580

Greenberg, M. and Chalk, P. and Willis, H. Khilko, I. and Ortiz, D. (2006) RAND Corporation: Maritime Terrorism - Risk \& Liability. [Online]. Available at: http://www.rand.org/pubs/monographs/MG520 [Accessed: 8th October 2010].

Gupta, D K. (2006) The Roots of Terrorism. Who are Terrorists? New York Infobase Publishing.

Hall, B P. (2009) Maritime Terrorism and Small Boat Threat to the United States: A Proposed Response. Published Thesis, Naval Postgraduate School, Monterey California. [Online]. Available at: http://pacnwest.org/docs/09Mar Hill.pdf [Accessed: 1st June 2011].

Hall, M. and Timothy, D. and Duval, D. (eds.) (2003) Safety and Security in Tourism: Relationships Management and Marketing. New York: Haworth Hospitality Press.

Hannafin, M. and Sarna, H. (2010) Cruises \& Ports of Call 2010: From U.S and Canadian Home Ports to the Caribbean, Alaska, Hawaii and More. New Jersey: Wiley Publishing.

Harrison, S. (ed.) (1999) Disasters and the Media: Managing Crisis Management Communications. Basingstoke: Macmillian Press.

Henderson, J C. (2003) Terrorism and Tourism: Managing the Consequences of the Bali Bombings. Journal of Travel and Tourism Marketing, vol. 15, p.41-58

Henderson, J C. (2007) Tourism Crisis: Causes, Consequences \& Management. Oxford: ButterworthHeinemann.

Hoffman, B. (2006) Inside Terrorism. New York: Columbia University Press.

Hofstede, G. (1980) Cultures Consequences: International Differences in Work Related Values. New York: SAGE Publications.

Hofstede, G. (2001) Cultures Consequences: International: Comparing Values, Behaviours, Institutions, and Organisations across Nations. $2^{\text {nd }}$ ed. New York: SAGE Publications.

Holloway, C, Davidson, R. and Humphreys, C. (2009) The Business of Tourism. $8^{\text {th }}$ ed. Harlow: Pearson Education.

Hosie, P. and Smith, C. (2004) Preparing for Crisis with Online Security Management Education. Research and Practice in Human Research Management, vol. 12, Issue 2, p.90-127. 
Jaques., T. (2007) Issue management and crisis management, an integrated non-linear relational construct. Public Relations Review Vol. 33 (2) pp 14-26.

Kavanagh, M. (2010) Sun4U Fall Raises Fears of More Failures. [Online]. Available at: http://www.ft.com [Accessed: $10^{\text {th }}$ January 2010].

Klein, R A. (2005) Cruise Ship Squeeze: The New Pirates of the Seven Seas. Gabriola Island: New Society Publishers.

Koknar, A. (2004) Terror on the High Seas. [Online]. Available at:

www.securitymanagement.com/article/terror-high-seas [Accessed: 4th July 2010].

Kucukaltan, D. (2006) Tourism and Terrorism. Lincoln: iuniverse.

Laws, E. and Prideaux, B. (2005) Crisis Management: A Suggested Typology. In: Laws, E and Prideaux, B. (eds.) Tourism Crises: Management Responses and Theoretical Insight. New York: Haworth Hospitality Press.

Laws, E. and Prideaux, B. (eds.) (2005) Tourism Crises: Management Responses and Theoretical Insight. New York: Haworth Hospitality Press.

Lepp, A. and Gibson, H. (2003) Tourist Roles, Perceived Risk and International Tourism. Annals of Tourism Research, vol. 30, Issue 3, p.606-624.

Luck, M. and Maher, P T. and Stewart, E J. (eds.) (2010) Cruise Tourism in Polar Regions: Promoting Environmental and Social Sustainability. London: Earthscan.

Mancini, M. (2004) Cruising: A Guide to the Cruising Industry. $2^{\text {nd }}$ ed. Montreal: Thomson Delmar Learning.

Mancini, M. (2011) The CLIA Guide to the Cruise Industry. New York: Delmar Cengage Learning.

Mansfeld, Y. and Pizam, A. (2006b) Tourism and Crisis Management Issues. In: Mansfeld, Y. and Pizam, A. (eds.) Tourism, Security \& Safety: From Theory to Practice. Oxford: Butterworth-Heinemann.

Mansfeld, Y. and Pizam, A. (eds.) (2006a) Tourism, Security \& Safety: From Theory to Practice. Oxford: Butterworth-Heinemann.

Mathews, M.C. (1987) Codes of ethics: organisational behaviour and misbehaviour. Research in Corporate Social Performance, Vol. 9, pp107-30

McKercher, B. and Pine, R. (2005) Privation as a Stimulus to Travel Demand. Journal of Travel \& Tourism Marketing, vol. 19, Issue, 2/3 p. 107-116.

McNicholas, M. (2008) Maritime Security: An Introduction. Oxford: Butterworth-Heinemann.

Meikle, J. (2010) French Court Blames US Airline and Mechanic for Paris Concorde Crash. [Online]. Available at: http://www.guardian.co.uk/world/2010/dec/06/concorde-crash-paris-airline-mechanic [Accessed: 17th May 2011].

Menee, S. (1988) Maritime terror in Europe and the Mediterranean. Marine Policy 12 (2): 143-152.

Mercola, J. (2011) New Body Scanners in Airports May be Unsafe. [Online]. Available at: http://patrickwarren.com/new-body-scanners-in-airports-may-be-unsafe [Accessed: 20th May 2011]. 
Minca, C. and Oaks, T. (eds.) (2006) Travel in Paradox: Remapping Tourism. Lincoln: Rowman and Littlefield Publishers.

Mitroff, I. (2004) Crisis Leadership: Planning for the Unthinkable. Los Angeles: University of Southern California.

Nathanson, S. (2010) Terrorism and the Ethics of War. Cambridge: Cambridge University Press.

Nieder, J W. and Enos, G. (2002) The Wake Up Call: Hope for the 9/11 Generation. Chicago. Xulon Press.

Nielsen, J N. (2008) The Future of Terrorism. [Online]. Accessed at:

http://geopolicraticus.wordpress.com/2008/11/18/the-future-of-terrorism [Accessed: 28th February 2011].

Niinien, O. and Gatsou, M. (2007) Crisis Management - A Case Study from the Greek Passenger Shipping Industry. Journal of Travel \& Tourism Marketing, vol. 23, p.191-202

Page, S. J. (2009) Transport and Tourism: Global Perspectives. 3rd ed. Harlow: Pearson Education Limited.

Page, S. J., Yeoman, I., Munro, C., Connell, J. and Walker, L. (2006) A case study of best practice VisitScotland's prepared response to an influenza pandemic. Tourism Management 27 (3) 361-392.

Page, S. J., Yeoman, I., Connell, J. and Greenwood, C. (2010) Scenario planning as a tool to understand uncertainty in tourism: The example of transport and tourism in Scotland in 2025. Current Issues in Tourism 13 (2): 99-137.

Passenger Shipping Association (2011) Cruising is Booming: Britons Cruise Industry rides the Crest of a Wave with Brits taking 1.62 Million Cruises. [Online]. Available at: http://www.the-

psa.co.uk/default.asp?PID $=20 \& P P I D=1 \& D I D=116$ [Accessed: $18^{\text {th }}$ May 2011].

Pforr, C. and Hosie, P J. (2007) Crisis Management in Tourism: Preparing for Recovery. Journal Travel \& Tourism Marketing, vol. 23, Issue, 2/3/4 p.249-264.

Pike, S. (2004) Destination Marketing Organisations. Oxford: Elsevier.

Pizam, A. and Fleischer, A. (2002) Severity versus Frequency of Acts of Terrorism: Which Has a Larger Impact on Tourism Demand? Journal of Travel Research, vol. 40, p.337-339.

Price, J C. and Forrest, J S. (2009) Practical Aviation Security: Predicting and Preventing Future Threats. Oxford: Butterworth-Heinemann.

Quartermaine, P. and Peter, B. (2006) Cruise: Identity, Design and Culture. London: Laurence King Publishing.

Quester, G. (1986) Cruise Ship Terrorism and the Media. Journal of Political Communication, vol. 3, issue 4,

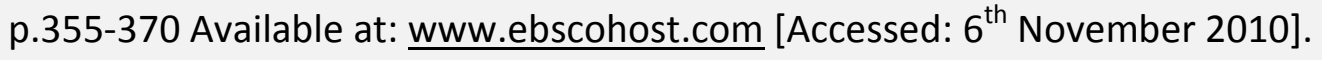

Rubackly, T. (2010) How Safe Are We At Sea? [Online]. Available at: http://www.cruisemates.com/articles/consumer/security.cfm\#axzz1NOEKJCRH [Accessed: $21^{\text {st }}$ May 2011].

Ruff, P. and Aziz, K. (2003) Managing Communications in a Crisis. Aldershot: Gower Publishing Limited.

Ruggero, R. (2011) New Cruise Ships for 2012. [Online]. Available at:

http://www.suite101.com/content/new-cruise-ships-for-2012-a340307 [Accessed: 23rd May 2011]. 
Santana, G. (2003) Crisis Management in Tourism: Beyond the Rhetoric. In: Hall, C M. Timothy, D J. and Duval, D T. (eds.) Safety and Security in Tourism: Relationships, Management and Marketing. New York: Haworth Press.

Sarantakos, S. (2005) Social Research. $3^{\text {rd }}$ ed. Basingstoke: Palgrave Macmillian.

Scott, N. and Laws, E. and Prideaux, B. (2007) Tourism Crisis and Marketing Recovery Strategies. Journal of Travel \& Tourism Marketing, vol. 23, Issue, 2/3/4 p.1 -13.

Sharpley, R. (2005) International Tourism: The Management of Crisis. In: Pender, L. and Sharpley, R. (eds) The Management of Tourism. London: Sage.

Skinner, C. and Mersham, G. (2002) Disaster Management: A Guide to Issues Management and Crisis Communication. Oxford: Oxford University Press.

Smith, V. (2005) Tourism and Terrorism: The New War. In: Aramberri, J and Butler, R. (eds.) Tourism Development: Issues for a Vulnerable Industry. Clevedon: Channel View Publications.

Sonmez, S F. and Graefe, A R. (1998) Influence of Terrorism Risk on Foreign Tourism Decisions. Annals of Tourism Research, vol.25, issue 1, p. 112-144.

Sonmez, S F. Apostolopoulos, Y. and Tarlow, P. (1999) Tourism in Crisis: Managing the effects of terrorism: (Special Issue on War, Terrorism, Tourism: Times of Crisis and Recovery). Journal of Travel Research, vol. 38, p. 3-8

Sonmez. S F. (1998) Tourism, Terrorism and Political Instability. Annuals of Tourism Research, vol. 25, issue 2, p.416-456.

Stevens, B. (1997)Hotel ethical codes: a content analysis. International Journal of Hospitality Management, Vol. 16 (3), pp261-71

Strafford, G. and Yu, L. and Kobina Armoo, A. (2006) Crisis Management and Recovery: How Washington DC, Hotels Responded to Terrorism. In: Mansfeld, Y and Pizam, A. (eds.) Tourism, Security \& Safety: From Theory to Practice. Oxford: Butterworth-Heinemann.

Stratton, A. (2010) Full body scanners being ordered for airports, says Gordon Brown. [Online]. Available at: http://www.guardian.co.uk/world/2010/jan/03/gordon-brown-airport-body-scanners [Accessed: 20th May 2011].

Swarbrooke, J and Horner S. (2004) International Case Studies in Travel and Tourism. Oxford, ButterworthHeinemann

Tally, W K. (2009) Port Economics. Oxford: Routledge.

Tarlow, P E. (2006a) A Social Theory of Terrorism and Tourism. In Mansfeld, Y and Pizam, A. (eds.) Tourism, Security \& Safety: From Theory to Practice. Oxford: Butterworth-Heinemann.

Tarlow, P E. (2006b) Terrorism and Tourism. In: Wilkes, J. and Pendergast, D and Leggat, P. (eds.) Tourism in Turbulent Times: Towards Safe Experiences for Visitors. Oxford: Elsevier.

Tate, P. (2002) The Impact of ' $9 / 11$ ': Caribbean, London and NYC Case Studies. Travel and Tourism Analyst, Vol. 5, p.1-25.

Terrorism Research (2011) Terrorist Groups. [Online]. Available at: http://www.terrorismresearch.com/groups [Accessed on 1st June 2011]. 
The Daily Telegraph Presents CRUISE (2011) The Daily Telegraph Presents CRUISE London 26-27 March 2011. [Online]. Available at: http://www.telegraph.co.uk/sponsored/travel/cruise-travel-show [Accessed on: 2nd March 2011].

Thomson, J. and Martin, F. (2010) Strategic Awareness: Management and Change. $6^{\text {th }}$ ed. Andover: Cengage Learning.

Timothy, D J. (2006) Safety and Security Issues in Tourism. In: Buhalis, D. and Costa, C. Tourism Management Dynamics: Trends, Management and Tools. Oxford: Butterworth-Heinemann.

Travel Mole (2011) Cruising Popularity Soars Despite Recession. [Online]. Available at: http://www.travelmole.com/stories/1146804.php [Accessed: 15th March 2011].

van der Heijden, K. (2003) Scenarios The Art of Strategic Conversation. Chichester: Wiley.

Veal A.J. (2006) Research Methods For Leisure \& Tourism. A Practical Guide. Third Edition, Pearson Education, Harlow, England.

Vesky, J P. (ed.) (2008) Port and Maritime Security. New York: Nova Science Publishers.

Volo, S. and Pardew, D. (2012) The Costa Concordia and similar tragic events: The mathematics and psychology of the loss and restoration of travellers' trust. Current Issues in Tourism in press.

Walker, J. and Walker, J. (2011) Tourism: Concepts and Practices. New Jersey: Pearson Education Inc.

Ward, D. (2010) Complete Guide to Cruising \& Cruise Ships 2010. $25^{\text {th }}$ ed. London: Berlitz Publishing. Warren, S. (2010) Full-body Airport Scanners face Further Delays Over Fears they Breach Child Born Laws. [Online]. Available at: http://www.dailymail.co.uk/news/article-1240738/Full-body-airport-scannerscreate-naked-images-pass-child-pornography-laws.html [Accessed: 24th May 2011].

Watson, R P. (2009) The Politics and History of Terror. In: Lansford, T. and Watson, R P. and Covarrubias, J. (eds.) Americas War on Terror.Aldershot: Ashgate Publishing.

Whittaker, D. J (2004) Terrorists and Terrorism: In the Contemporary World. London: Routledge.

Wilkes, J. and Pendergast, D and Leggat, P. (eds.) (2006) Tourism in Turbulent Times: Towards Safe Experiences for Visitors. Oxford: Elsevier.

Yarnal . C., Kerstetter., D and Yen I-Y (2005) So why haven't you taken a cruise lately? Tourism Review International, 8(3): 231-296.

Zikmund, W.G. (1997) Business Research Methods, $5^{\text {th }}$ Edition. Orlando, Florida, Dryden Press. 